\title{
BRITISH BEE-KEEPER'S
}

\section{PRACTICAL NOTE-BOOK}

THOS. WM. COWAN, F.L.S., F.G.S., ETC. 


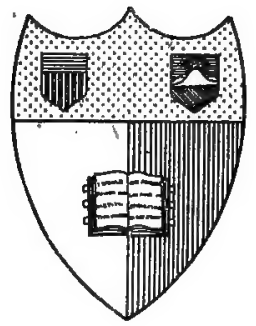

\section{Avew 甚ark \\ State (Ụllege of Agriculture \\ At Garnell Ilniuersity \\ Jtḩara, 2.}

\section{Withrary}




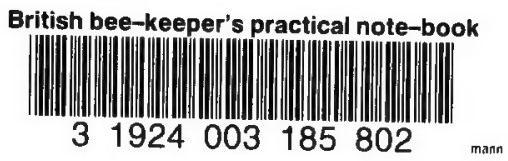




\section{Cornell University Library}

The original of this book is in the Cornell University Library.

There are no known copyright restrictions in the United States on the use of the text. 


\section{BRITISH BEE-KEEPER'S}

\section{PRACTICAL NOTE-BOOK}

FOLLOWED BY A DESCRIPTION OF

THE ' W. B. C.' HIVE AND HOW TO MAKE IT, A HOME-MADE HIVE FROM USED BOXES, HOW

TO BUILD A BEE HOUSE, AND SHORT RULES FOR THE MANAGEMENT OF MOVEABLE COMB-HIVES.

BX

THOS. WM. COWAN, F.L.S., F.G.S., F.R.M.S., ETC.

Chairman British Bee-ke6pers' Association; Editor of "British Bee Journal ;"

Author of 'The Honey Bee : Its Natural History, Anatomy, and Physiology," 'The British Bee-kesper's Guide-book,

'Foul Brood and its Treatment, 'Boes and their Management,'

'Wintering Bees,' Doubling and Storifying,'

- How to Make an Extractor and Bellows Smoker, etc; Member of the British Association for the Advancement of Science; Honoravy Member of several Bee-keepers' Assobiations in Europe and America, otc. otc.

Second Idition.

LONDON :

HOULSTON \& SONS, PATERNOSTER SQUARE, $\triangle N D$

'British Bee Journat \& Bee-Keepers' Record' OfHJCe, 10 Buckingham Street, Strand, W.C.

All Rights Reserved. 


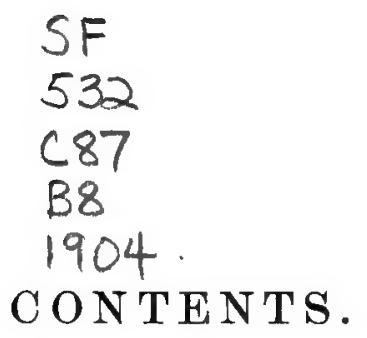

PAGE

INTRODUCTION . . . . . . . . . . . . . . 3

Table I.-Daily Observations . . . . . . . 4-15

" II.-ObGervationg dURIng Wrnter . . . 16-21

" III.-Observations Regpecting Queens 22, 23

" IV.-Queen Rearing. . . . . . . . . 24, 25

" V.-Number of Brood Combs, \&c. . . . 26-29

"VI.-Swarms . . . . . . . . . . . . 30, 31

"VII.-Produce of THe Year . . . . . . 32, 33

„VIII.-Food TABLE. . . . . . . . . . . 34-49

" IX-Autumnal Inspection . . . . . . 40-43

"X.-Wintering TABLE . . . . . . . . 44-47

" XI.-Inventory of Stocks . . . . . . . . 48,49

"XII.-Income and Expenditure. . . . . 50-53

The 'W.B.O.' Hive: How to Make It . . . . 54-62

A Home-made Hive . . . . . . . . . . . 63-65

How to Butrd a Bee-House . . . . . . . . 65-68

Short Rules for General Management . . . 69-71 


\section{N T R O D UCTION.}

THEN a bee-keeper has only a few stocks of bees, and these are kept for amusement, it matters very little whether he keeps a note-book or not; but when a large number of bees are kept for profit, it is absolutely necessary that accurate entries be made of all observations and operations. There being no satisfactory notebook to assist the bee-keeper in this work, the following Tables have been arranged in the hope that they may supply a long-felt want, frequently expressed to the author. There are sufficient Tables for one year's entries in a large apiary, and the moderate price at which this Note-book is issued will place it within the reach of every bee-keeper. To those who are in a position to do so, it would greatly assist the science if they would record observations with respect to the weather, and for this purpose Tables I. and II. will be found useful. At present very little is known as to the relation of the secretion of nectar in plants in regard to the weather, and if reliable statistics from various districts could be collected for a number of years, the laws regulating the production of honey might be discovered.

Most of the other Tables are so simple as to require no explanation.

Chapters on making hives and bee-houses have been added in this edition in response to the frequent applications for this information.

This Note-book is intended as a pocket companion for the bee-keeper, therefore a few rules on general management of bees, such as he may require, are given at the end.

For the complete and practical management of bees in moveable-comb hives the bee-keeper is referred to the British Bee-keeper's Guide-book, by the same author.

10 Buckingham Street, Strand, London, W.C., Jan. 1904. 
4 I.-DAILY OBSERVATIONS FROM SPRING TO AUTUMN. Month of Year

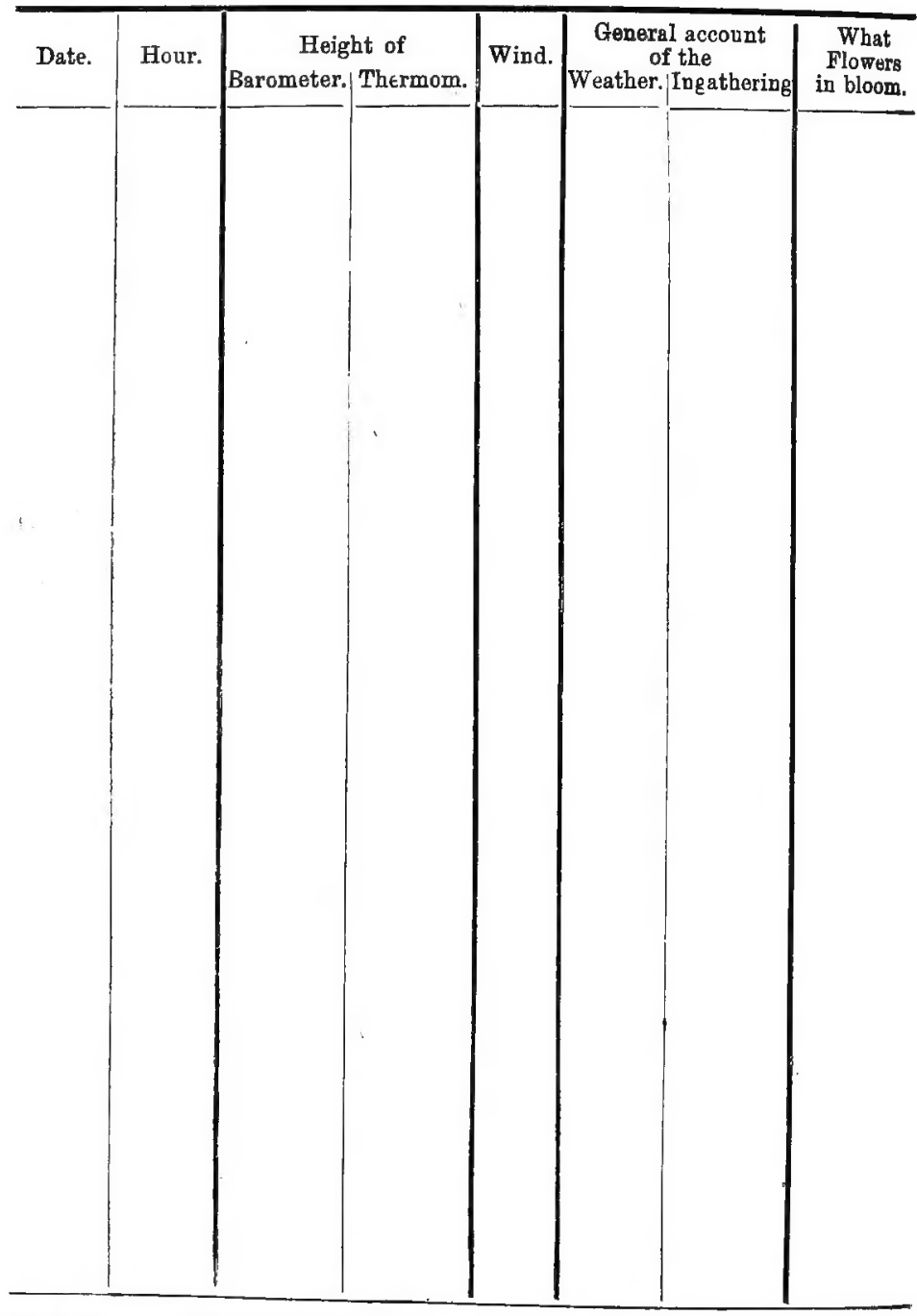


6 I.-DAJLY OBSERVATIONS FROM SPRING TO AUTUMN.

Month of

Year

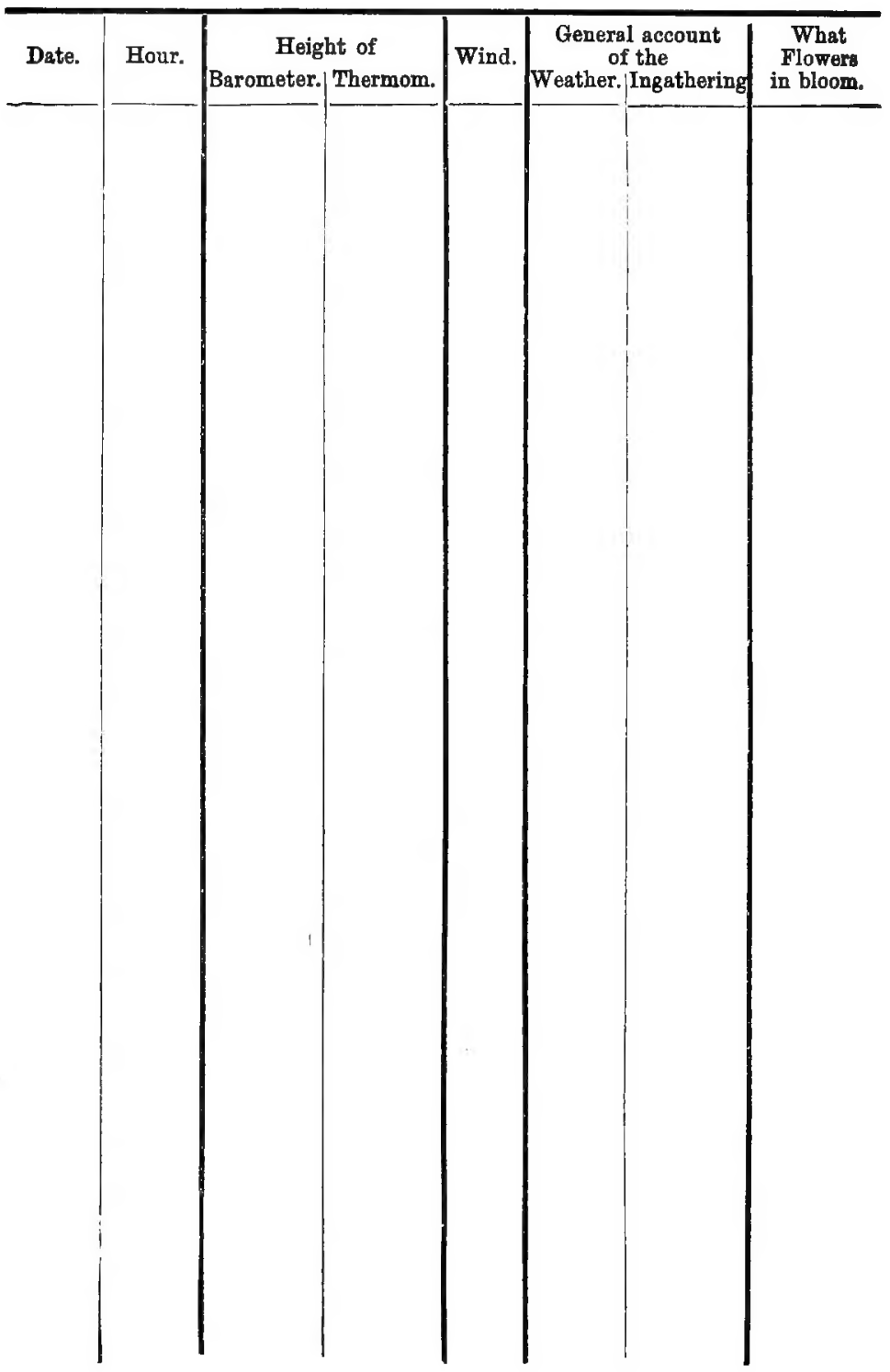


GENERAL OBSERVATIONS. 

GENERAL OBSERVATIONS. 
10 I.-DAILY OBSERVATIONS FROM SPRING TO AUTUMN. Month $0 \quad$ Year

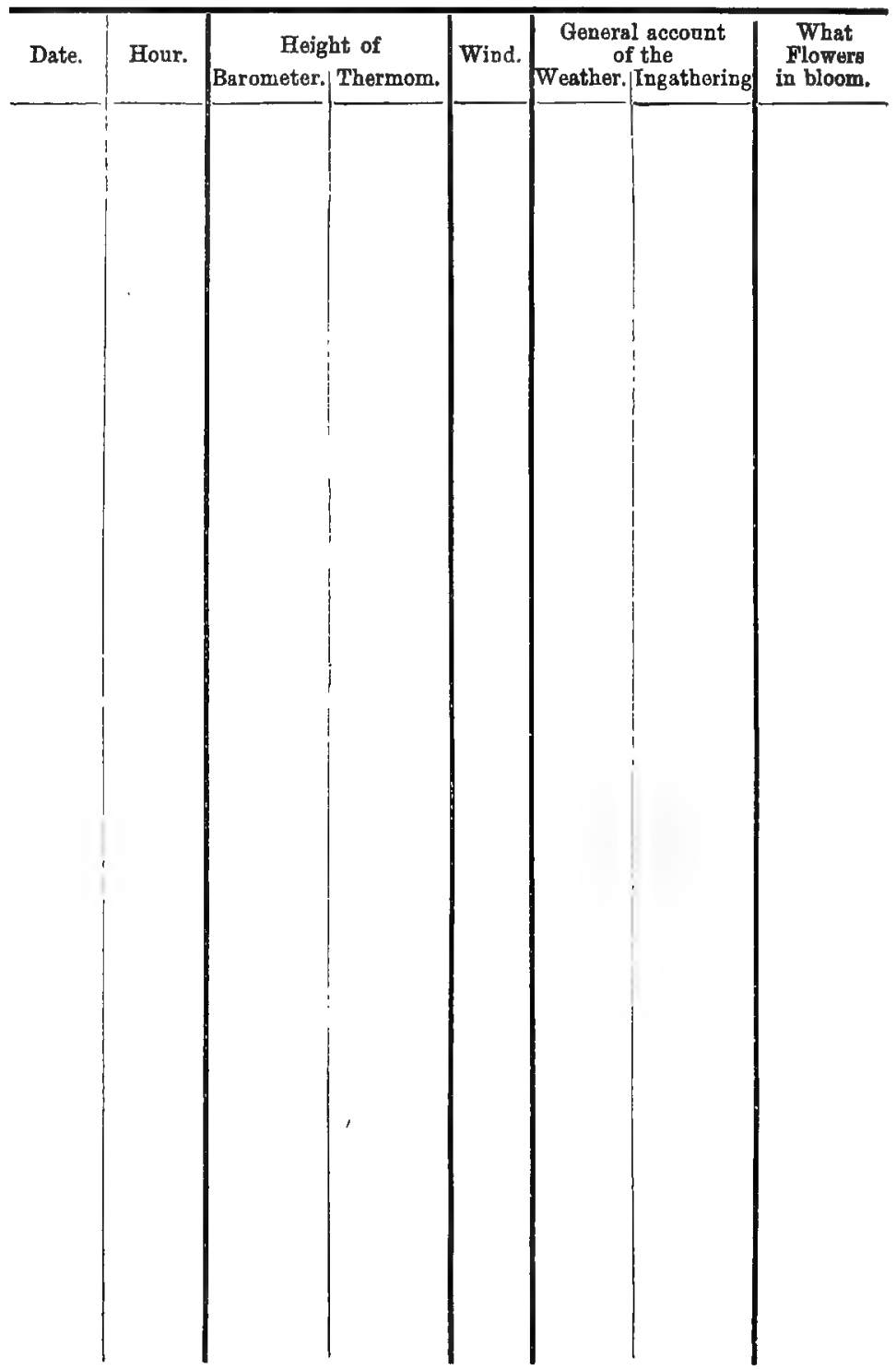


12 I.-DAILY OBSERVATIONS FROM SPRING TO AUTUMN. Month of Year

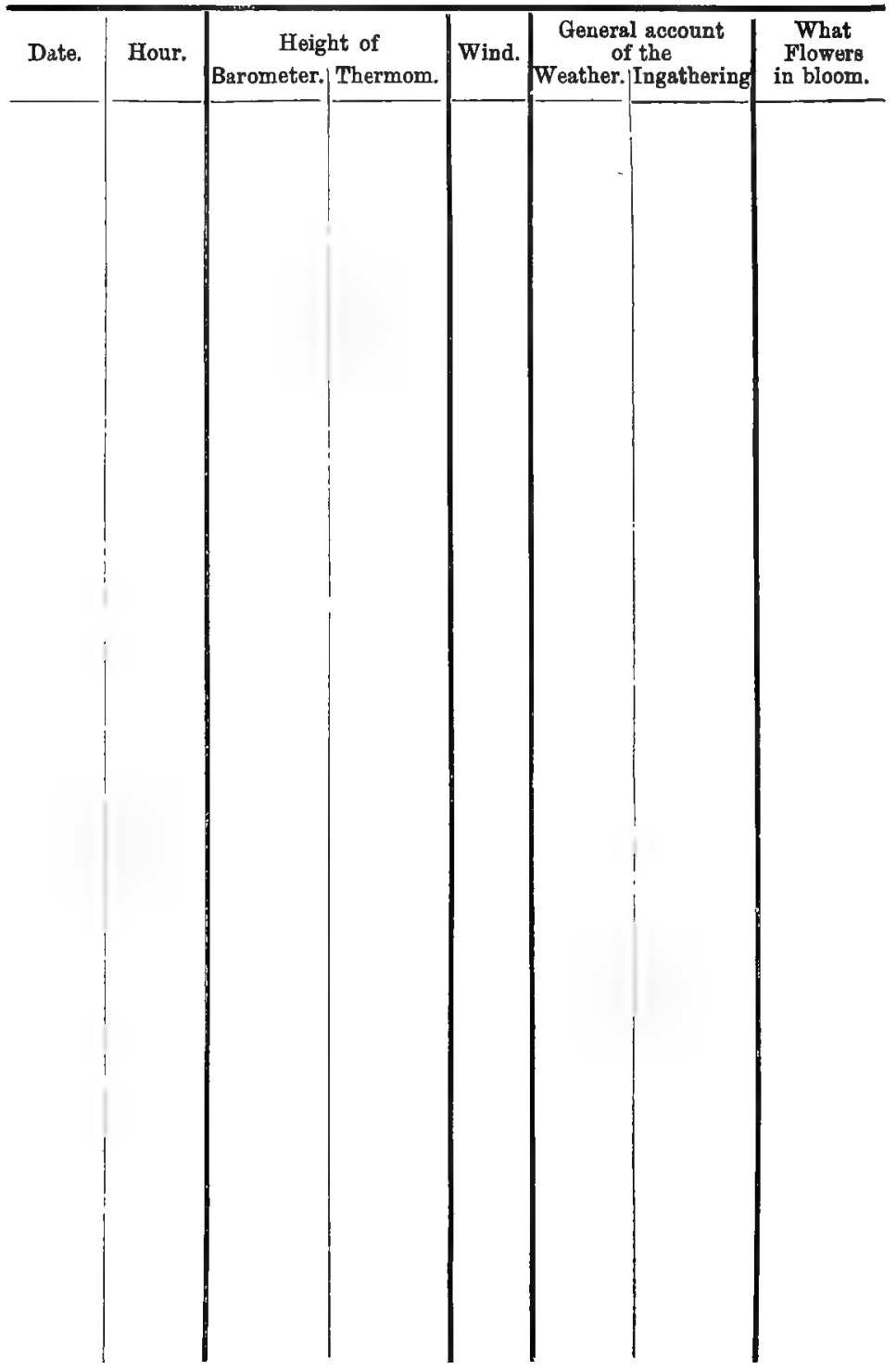



GENERAL OBSERVATIONS. 
Month Year

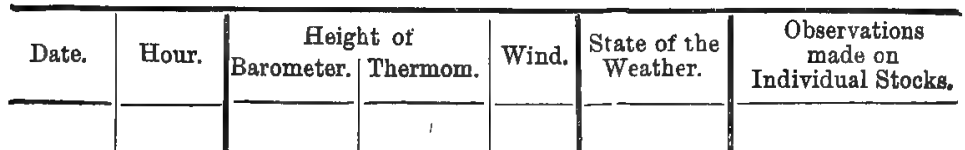


II.-OBSERVATIONS DURING WINTER.

Month

Year

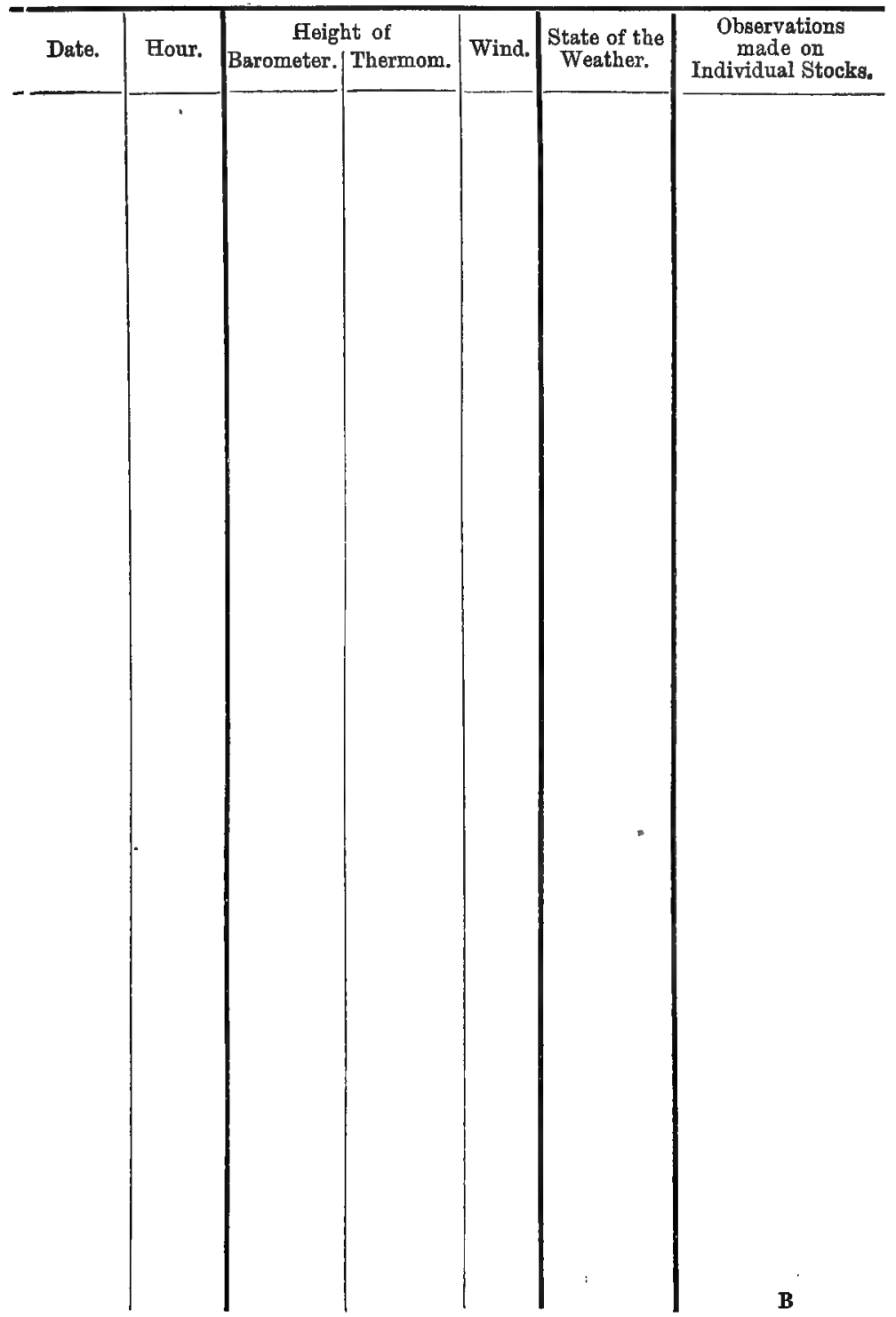


18

II. -OBSERVATIONS DURING WINTER.

Month

Year

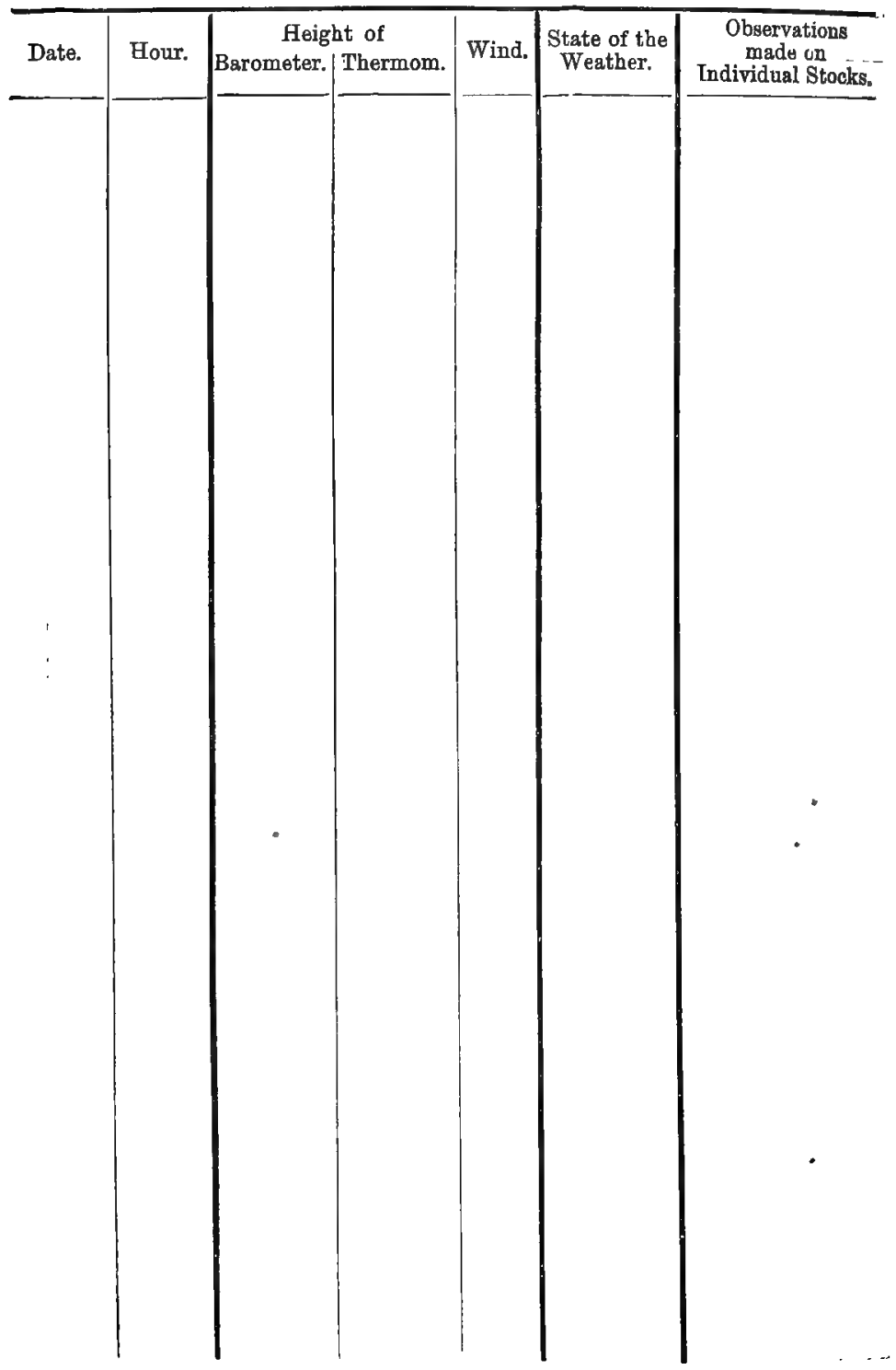




$$
\pi
$$


20

II.-OBSERVATIONS DURING WINTER.

Month

Year

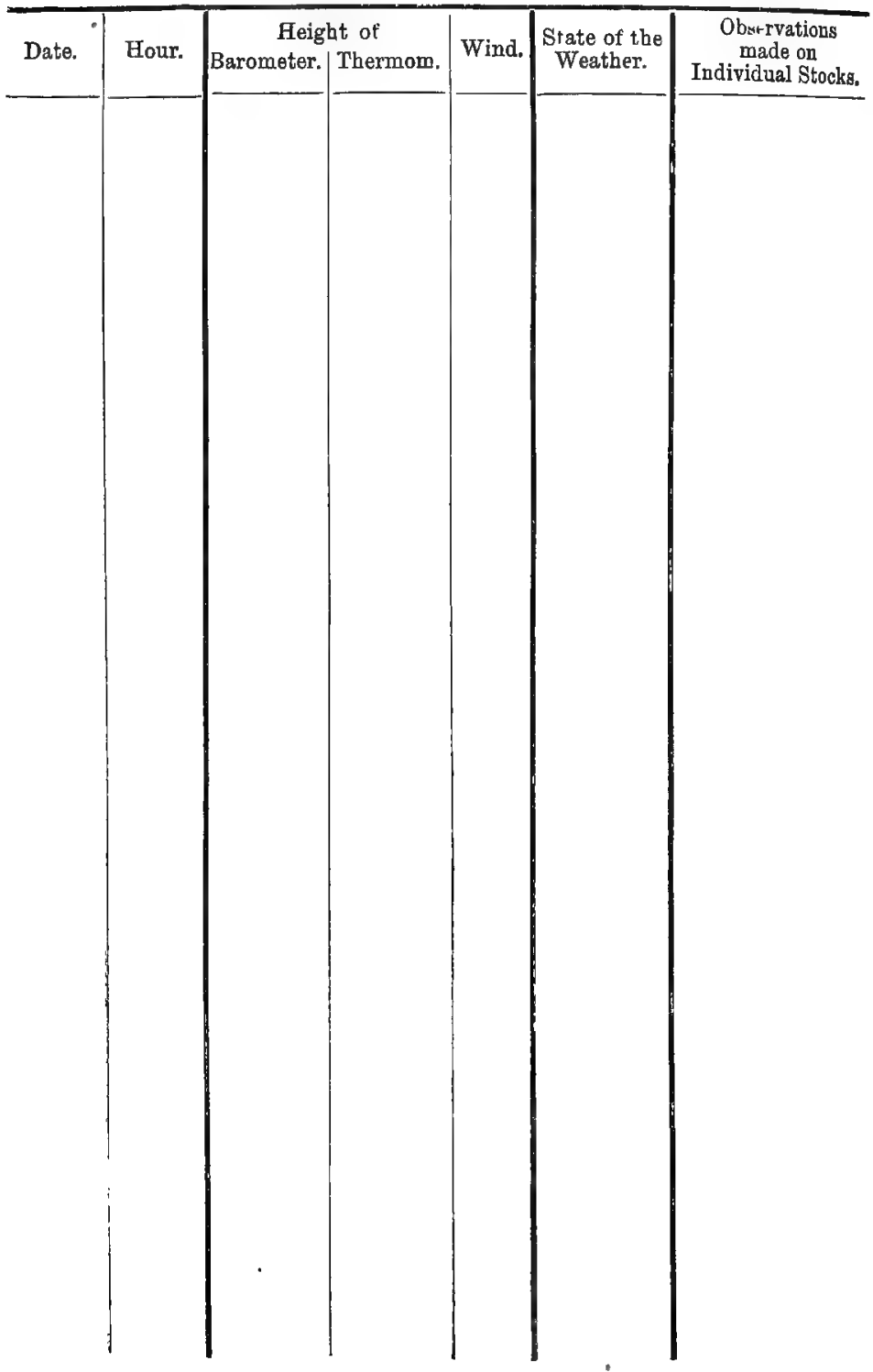



22

III.-OBSERVA'TIUNS KESPEUIING QUEENS.

Year

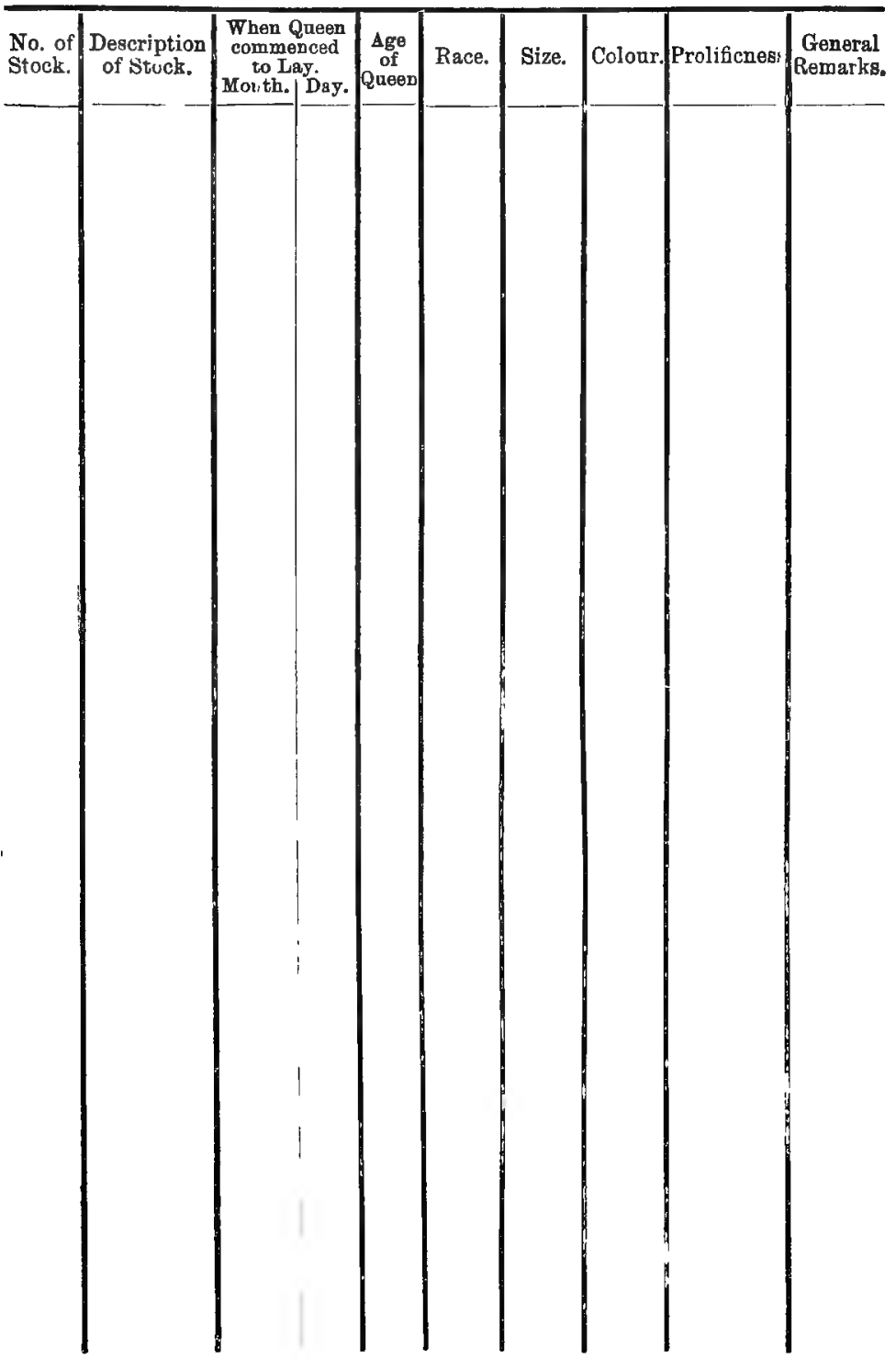


Year

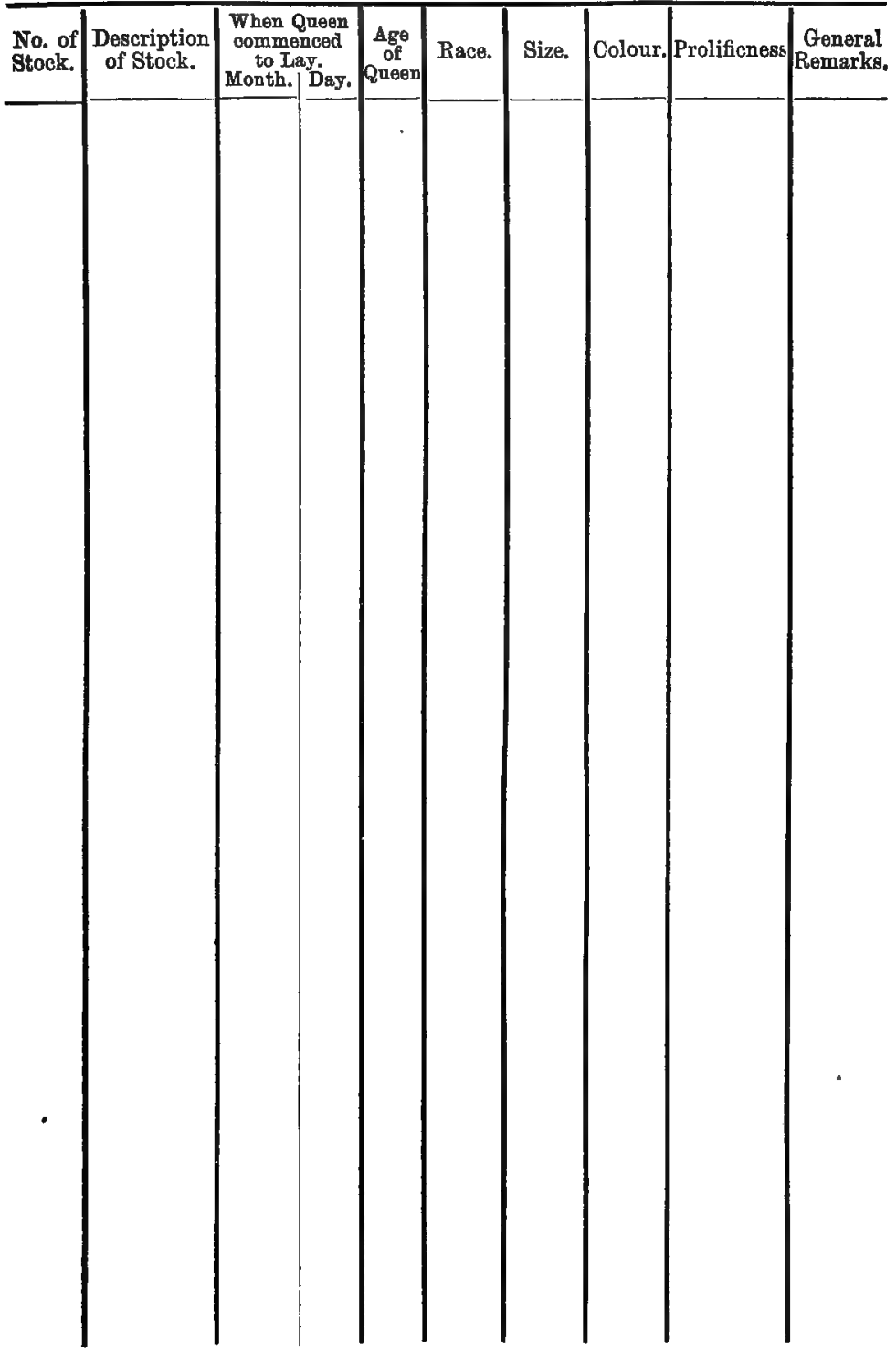


24

IV.-QUEEN REARING.

Year

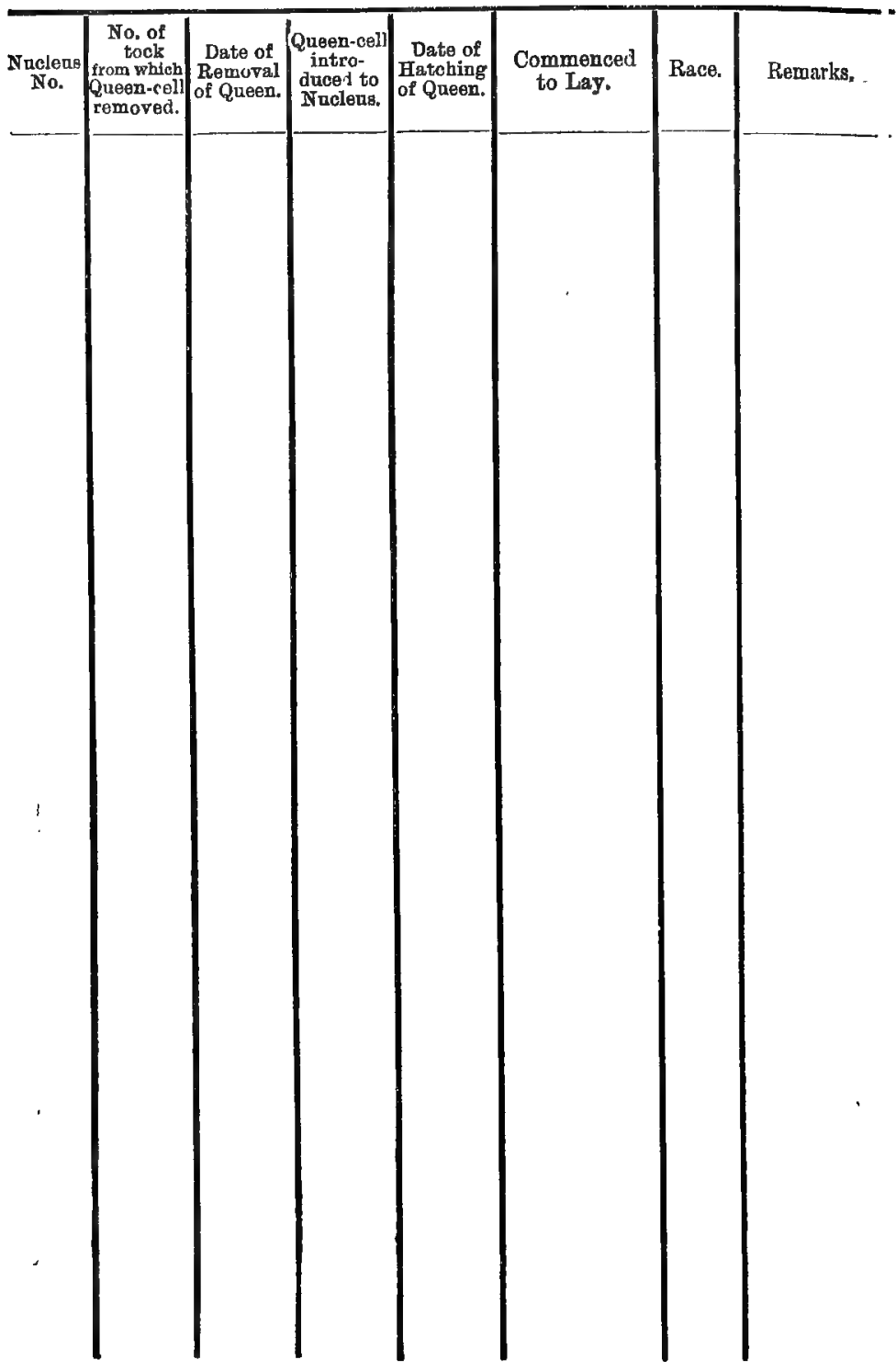


Year

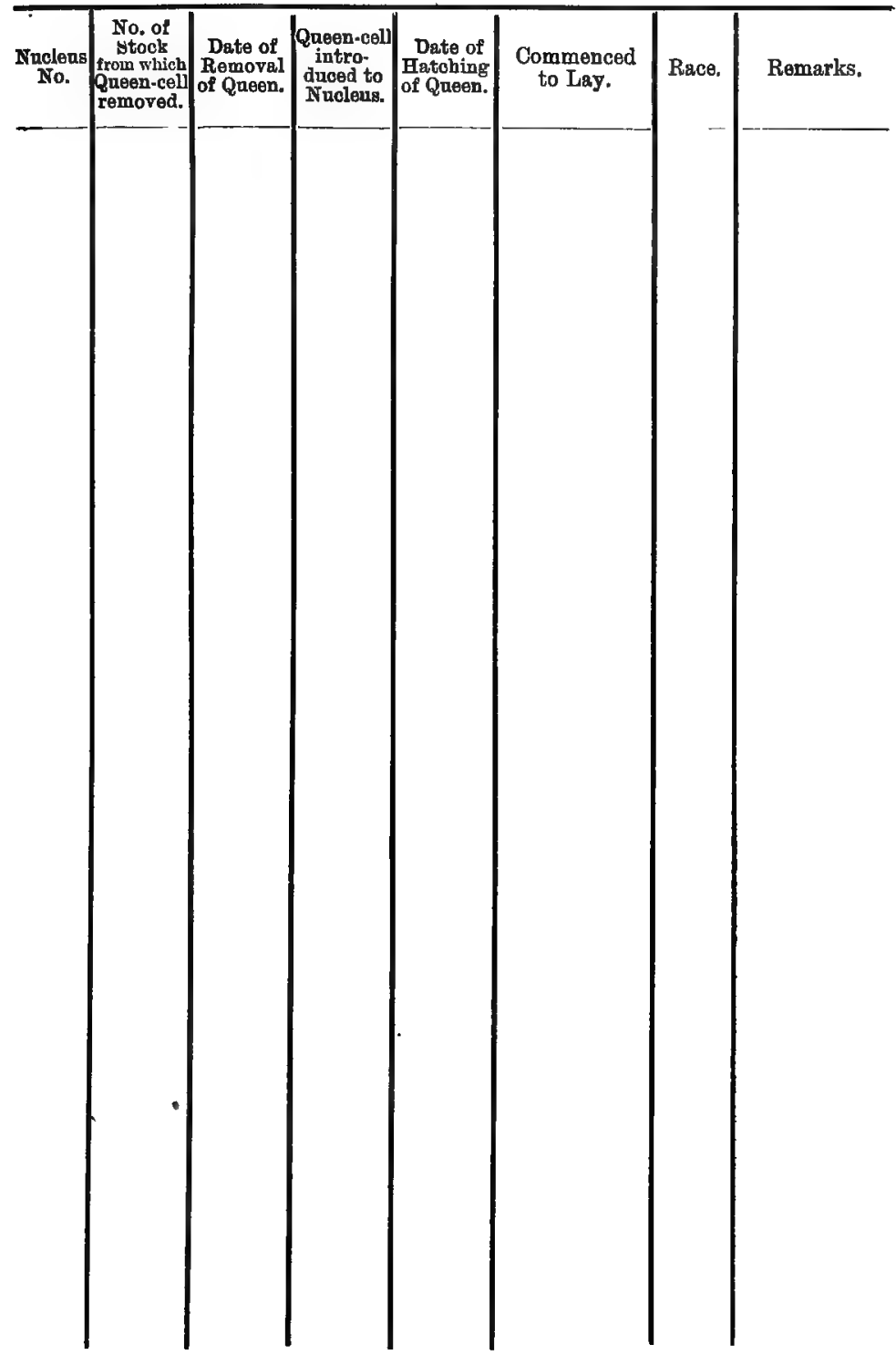




\section{Month}

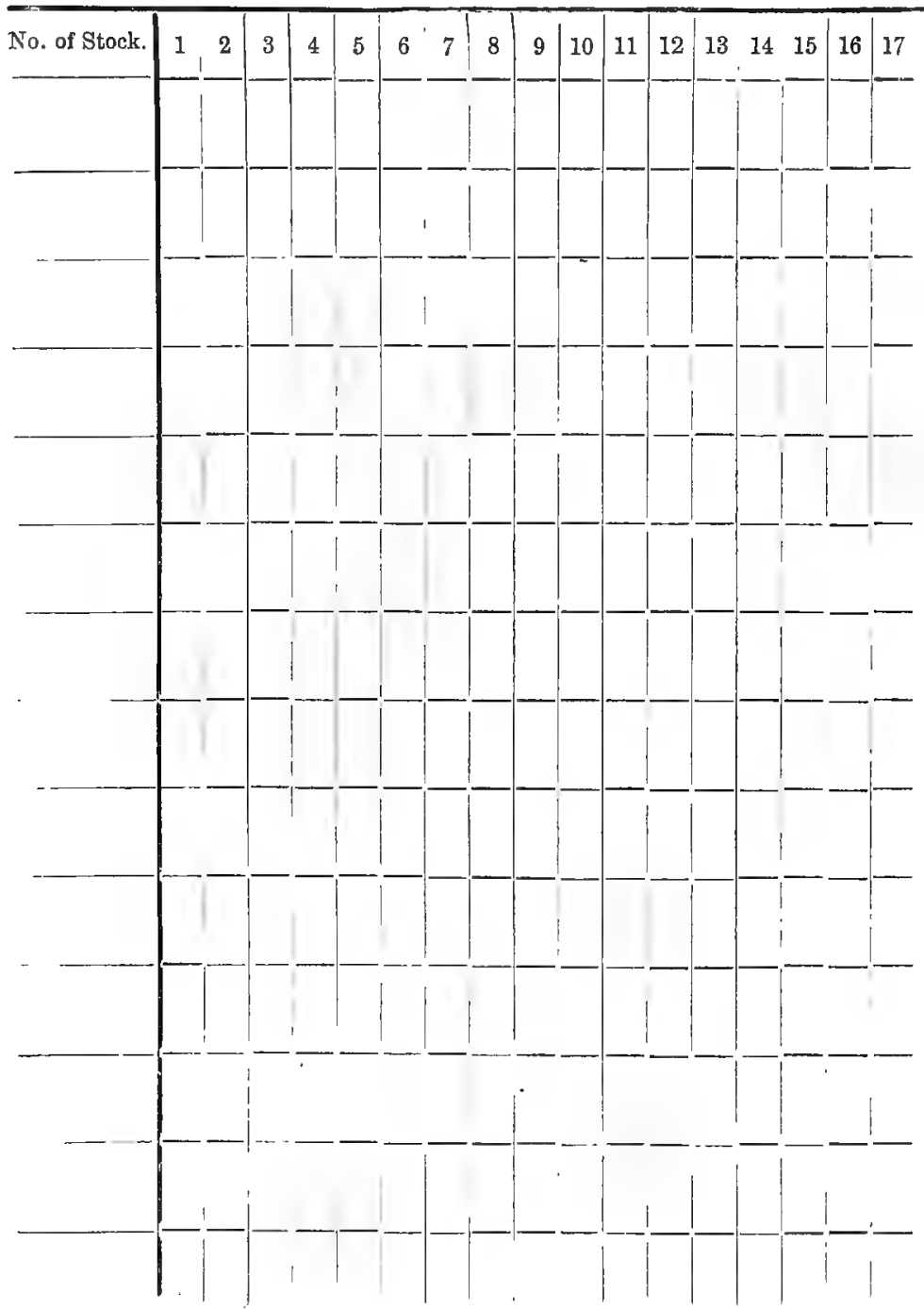


Spring of 190 .

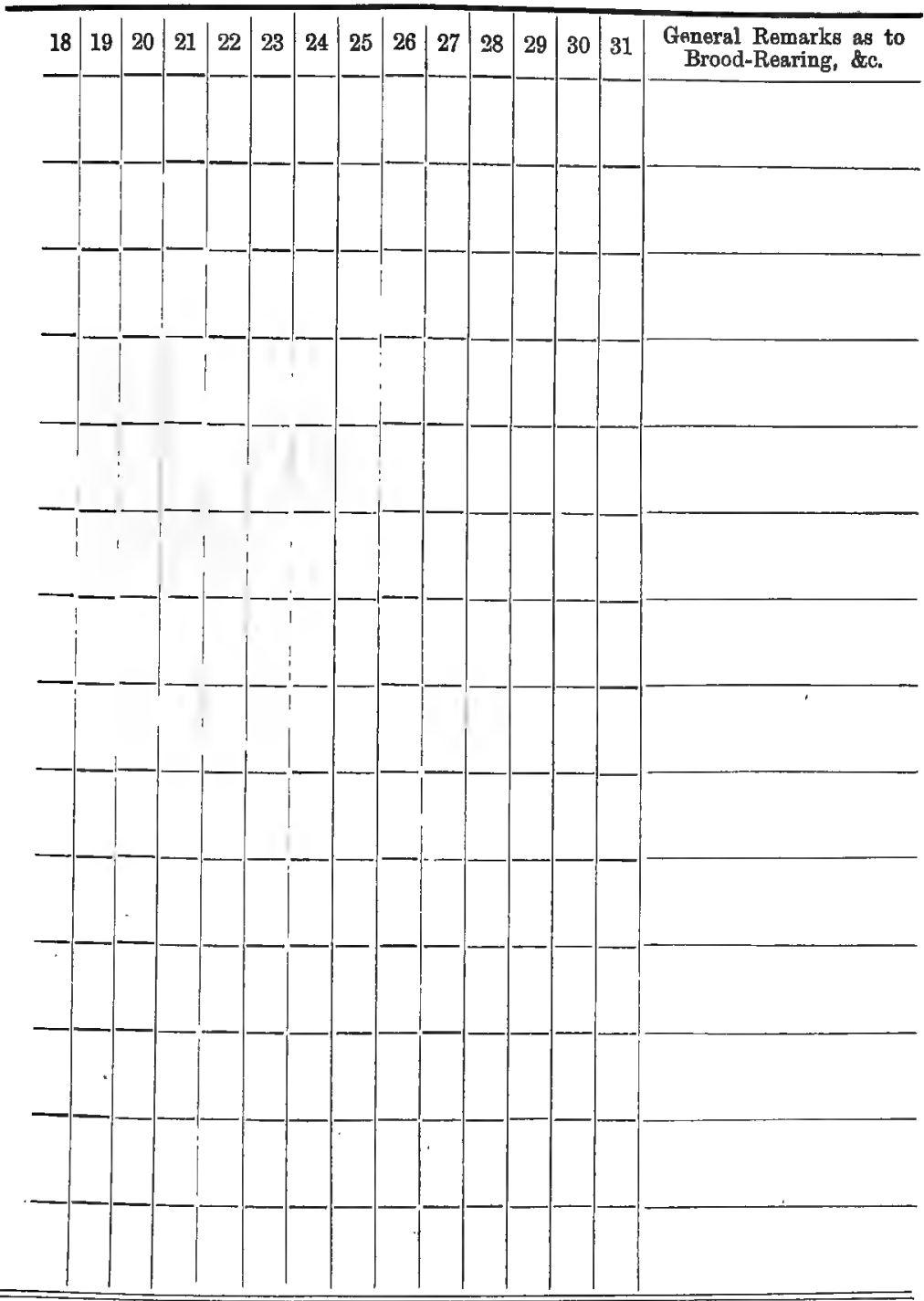

$\begin{array}{lllllllllllll}1 & \mid & \mid & 7 & 1 & 1 & 1 & 1 & 1 & \mid & 1 & 1 & \mid 11\end{array}$ 


\section{Month}

\begin{tabular}{|l|l|l|l|l|l|l|l|l|l|l|l|l|l|l|l|l|l|}
\hline No. of Stock. & 1 & 2 & 3 & 4 & 5 & 6 & 7 & 8 & 9 & 10 & 11 & 12 & 13 & 14 & 15 & 16 & 17
\end{tabular}


Spring of 190 .

\begin{tabular}{l|l|l|l|l|l|l|l|l|l|l|l|l|l|l|}
18 & 19 & 20 & 21 & 22 & 23 & 24 & 25 & 26 & 27 & 28 & 29 & 30 & 31 & $\begin{array}{c}\text { General Remarks as to } \\
\text { Brood-Rearing, \&c. }\end{array}$ \\
\hline
\end{tabular}




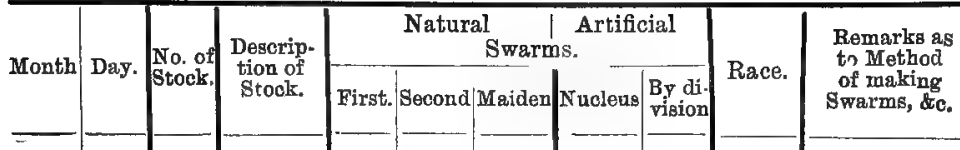

$\pm$ 


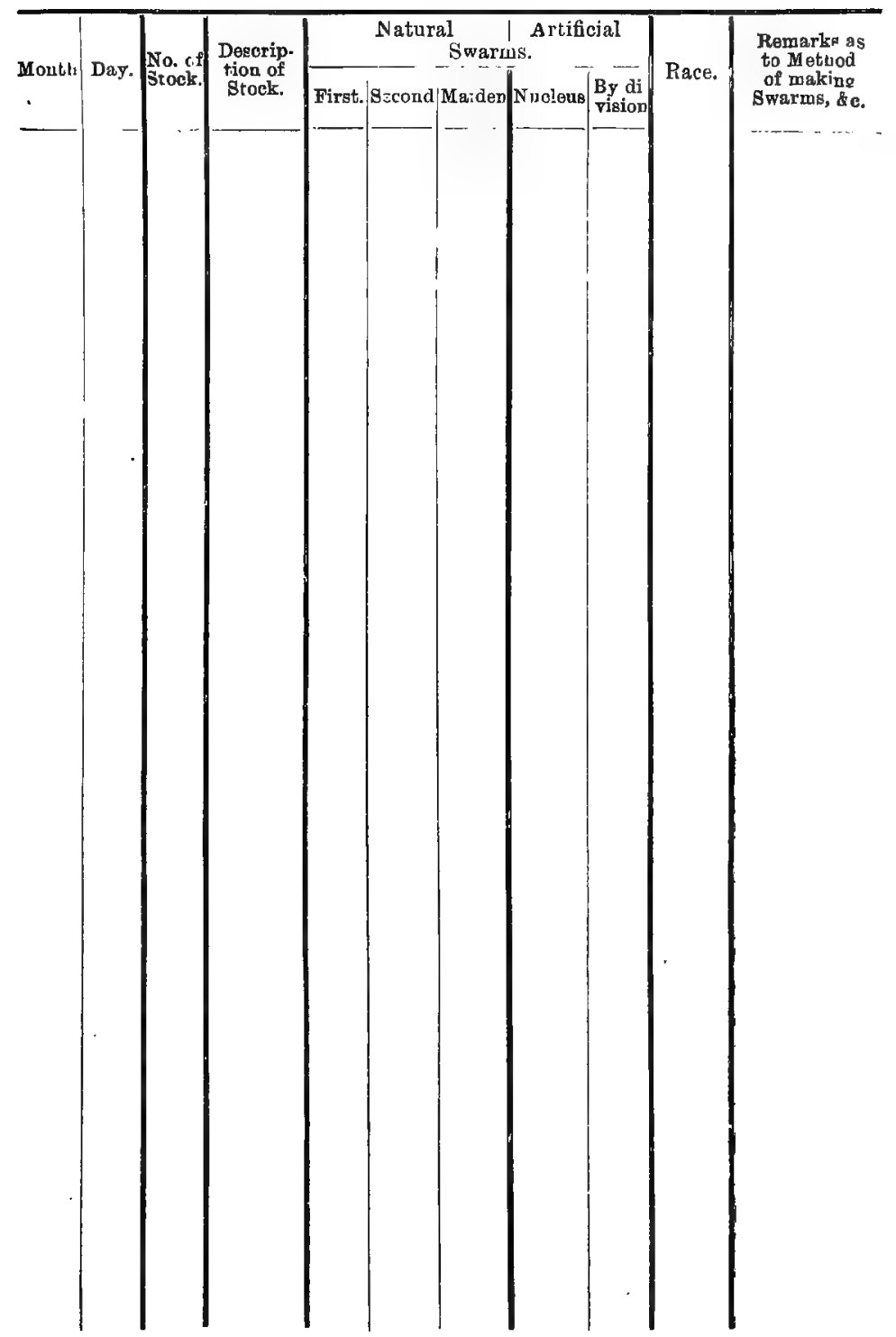


Honey and Wax.

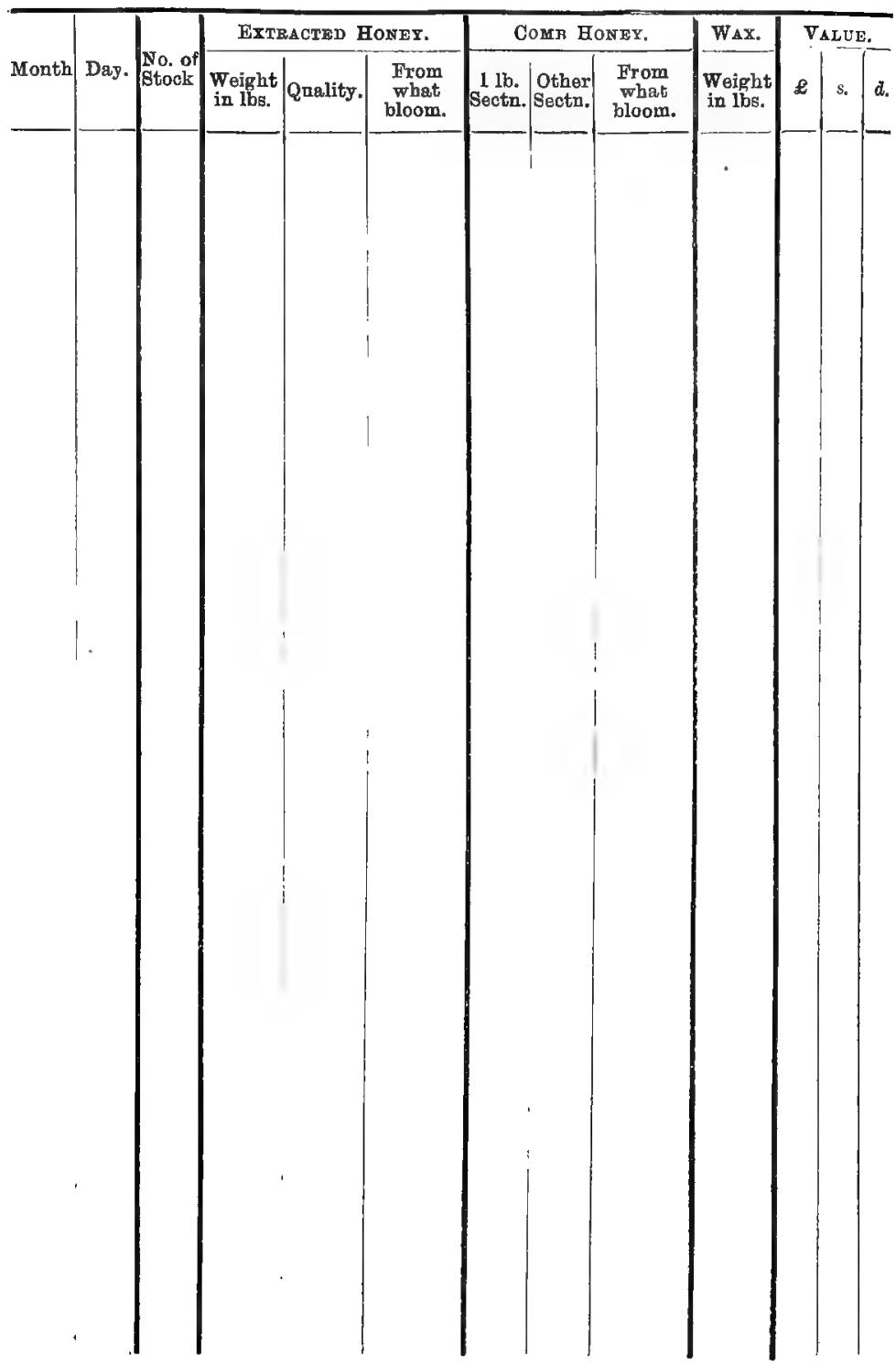


HoNEY AND WAX.

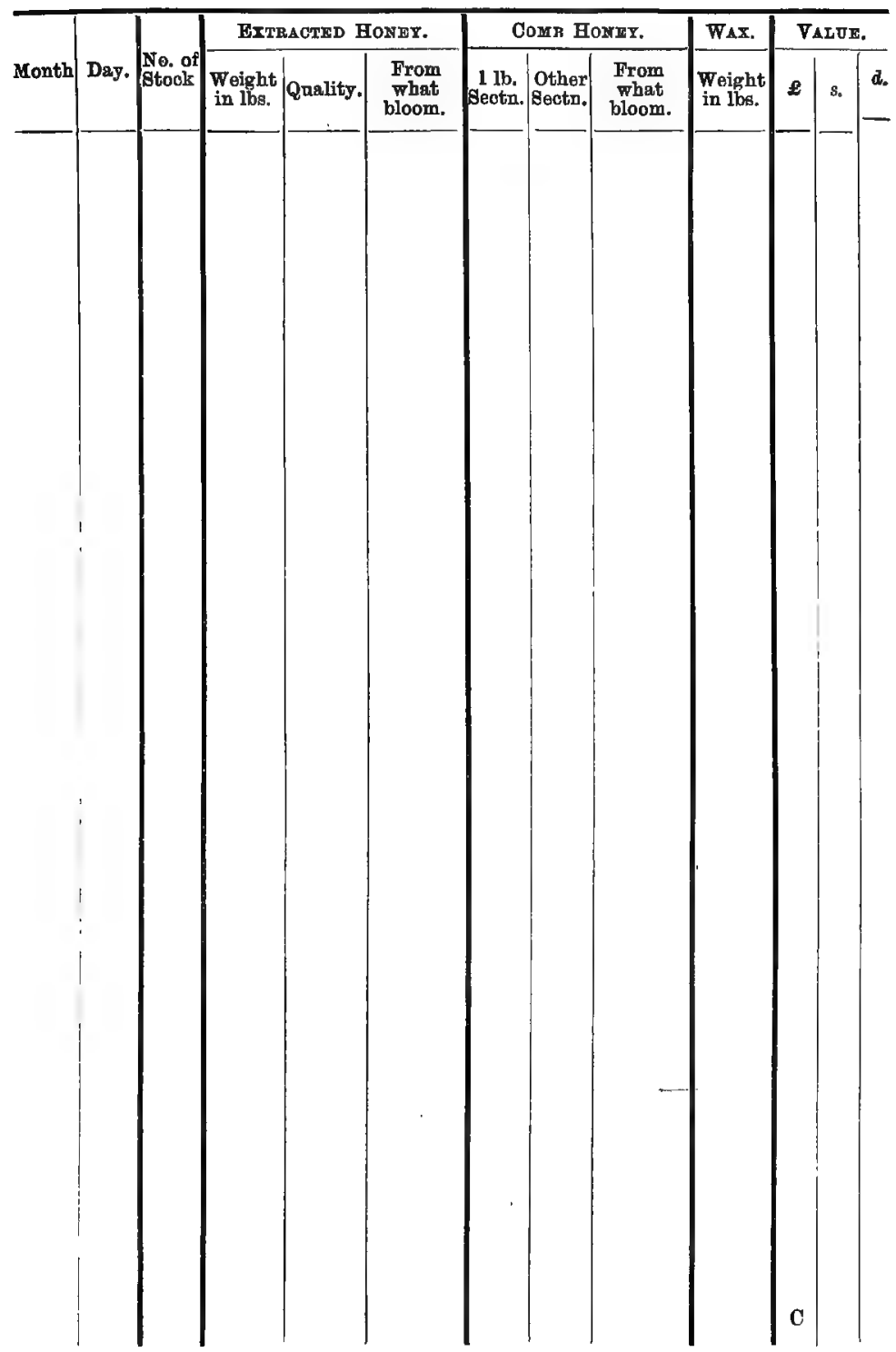




$$
\mathbb{T I}
$$




$$
\pi
$$


36 VIII. -FOOD TABLE AND GENERAL REMARKS ON EACH STOOK.

Year

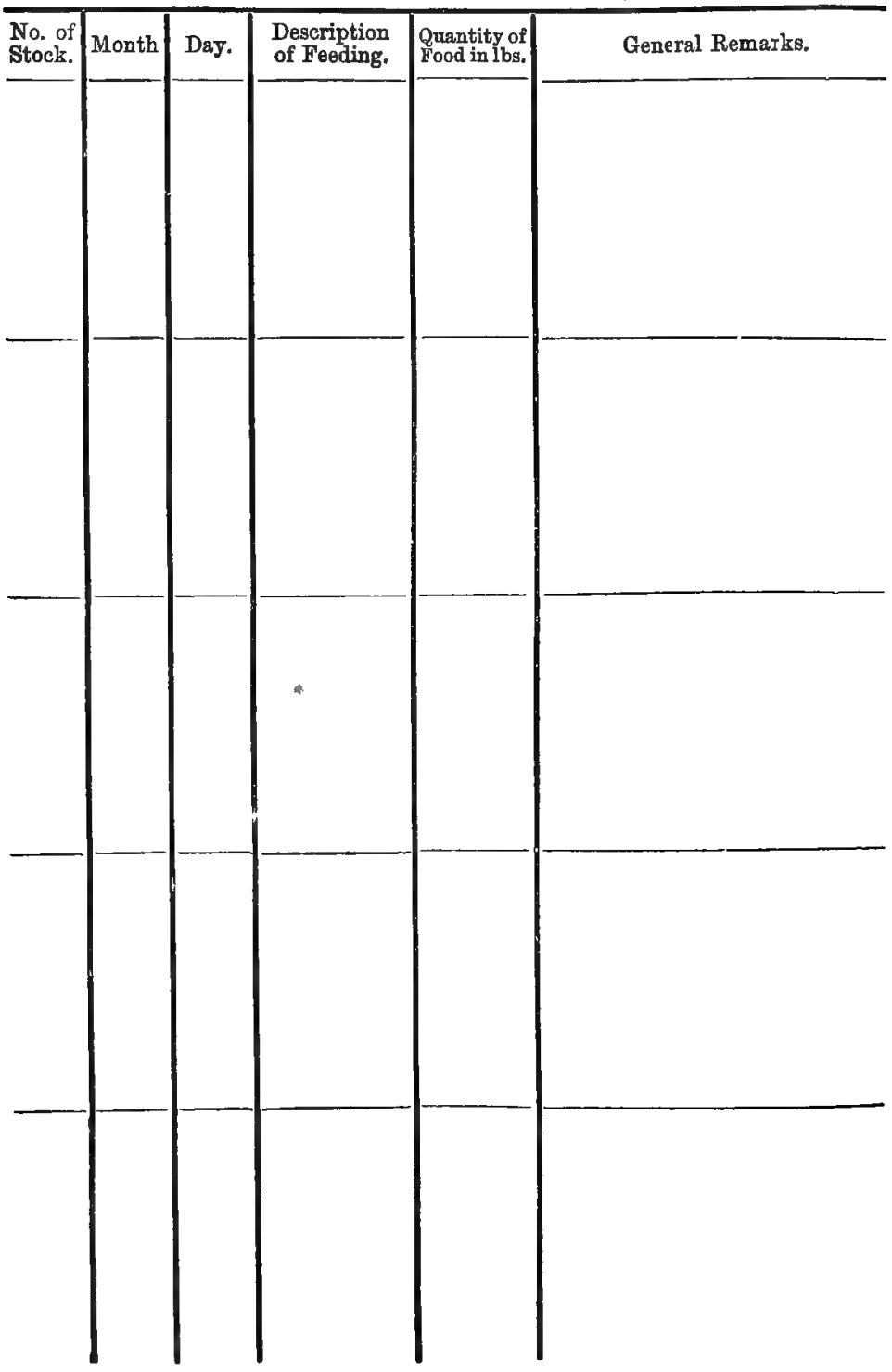


VIII. FOOD TABLE $\triangle$ ND GENERAL REMARKS ON EACH STOCK, 37 Year

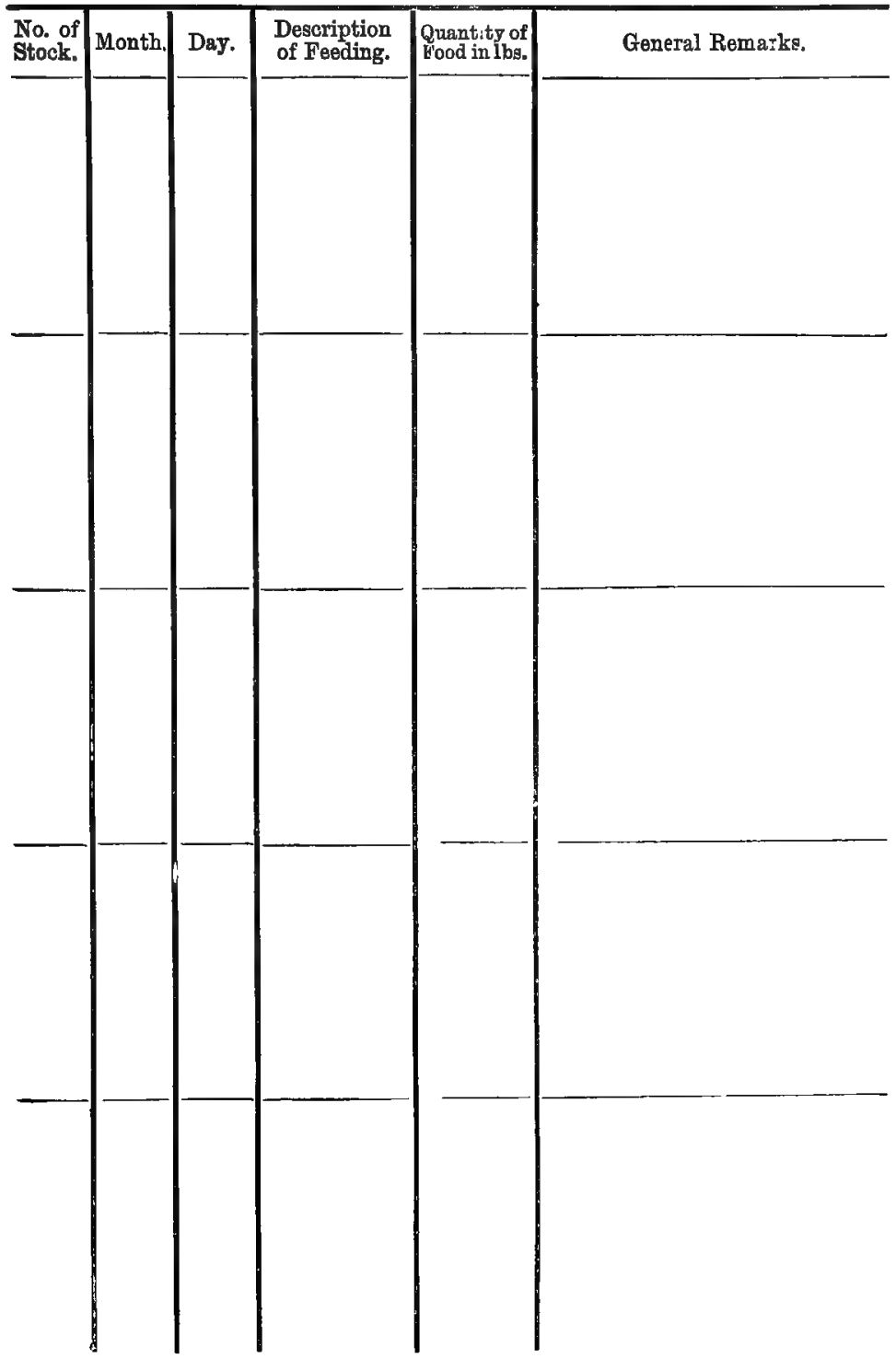




\begin{tabular}{l|l|l} 
& \\
\hline & &
\end{tabular}




$$
\mathbb{\pi}
$$




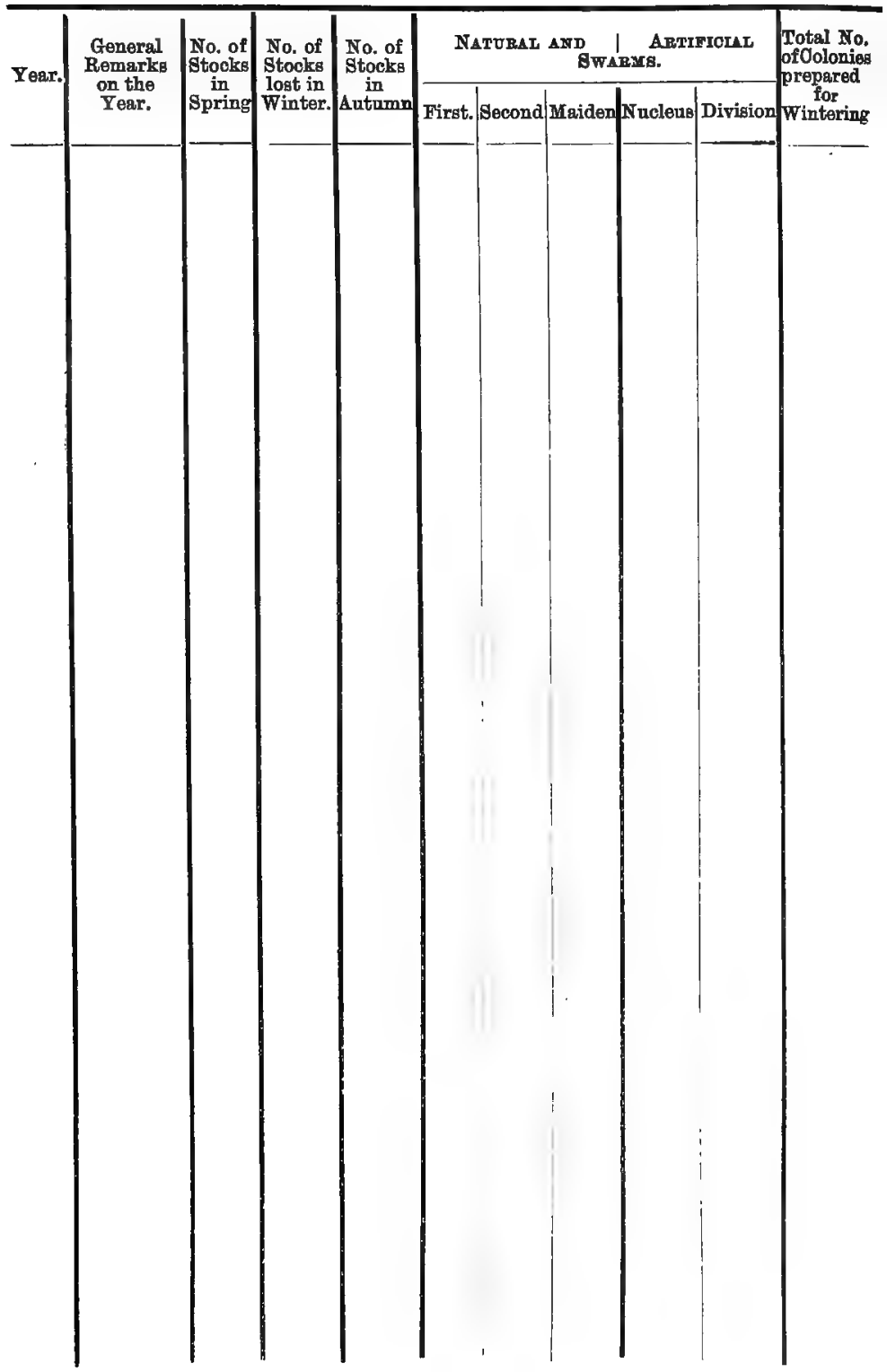




\begin{tabular}{|c|c|c|c|c|c|c|c|c|c|c|c|c|c|c|c|c|}
\hline \multirow{2}{*}{\multicolumn{2}{|c|}{$\frac{\text { ProDUCE IN }}{\text { Fixtracted. }}$}} & \multicolumn{3}{|c|}{ HONBY AID WAX. } & \multicolumn{3}{|c|}{$\begin{array}{l}\text { Value of } \\
\text { Produce. }\end{array}$} & \multirow{2}{*}{$\begin{array}{c}\text { Value of } \\
\text { Bees sold. } \\
-\end{array}$} & \multirow{2}{*}{\multicolumn{2}{|c|}{$\begin{array}{l}\text { Total } \\
\text { Income. }\end{array}$}} & \multicolumn{3}{|c|}{$\begin{array}{l}\text { Total Ex- } \\
\text { penditure. }\end{array}$} & \multicolumn{3}{|c|}{$\begin{array}{l}\text { Profit per } \\
\text { Stock. }\end{array}$} \\
\hline & & Oomb & Honey. & & & & & & & & & & & & & \\
\hline Quat & Quality. & Section & $\begin{array}{l}\text { Other } \\
\text { sixes. } \\
\end{array}$ & Wax. & $\boldsymbol{L}$ & $\begin{array}{l}\text { s. } \\
-\end{array}$ & $d$. & 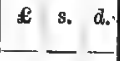 & $\mathscr{L}$ & s. d. & $\mathfrak{E}$ & s. & d. & $£$ & s. & \\
\hline
\end{tabular}




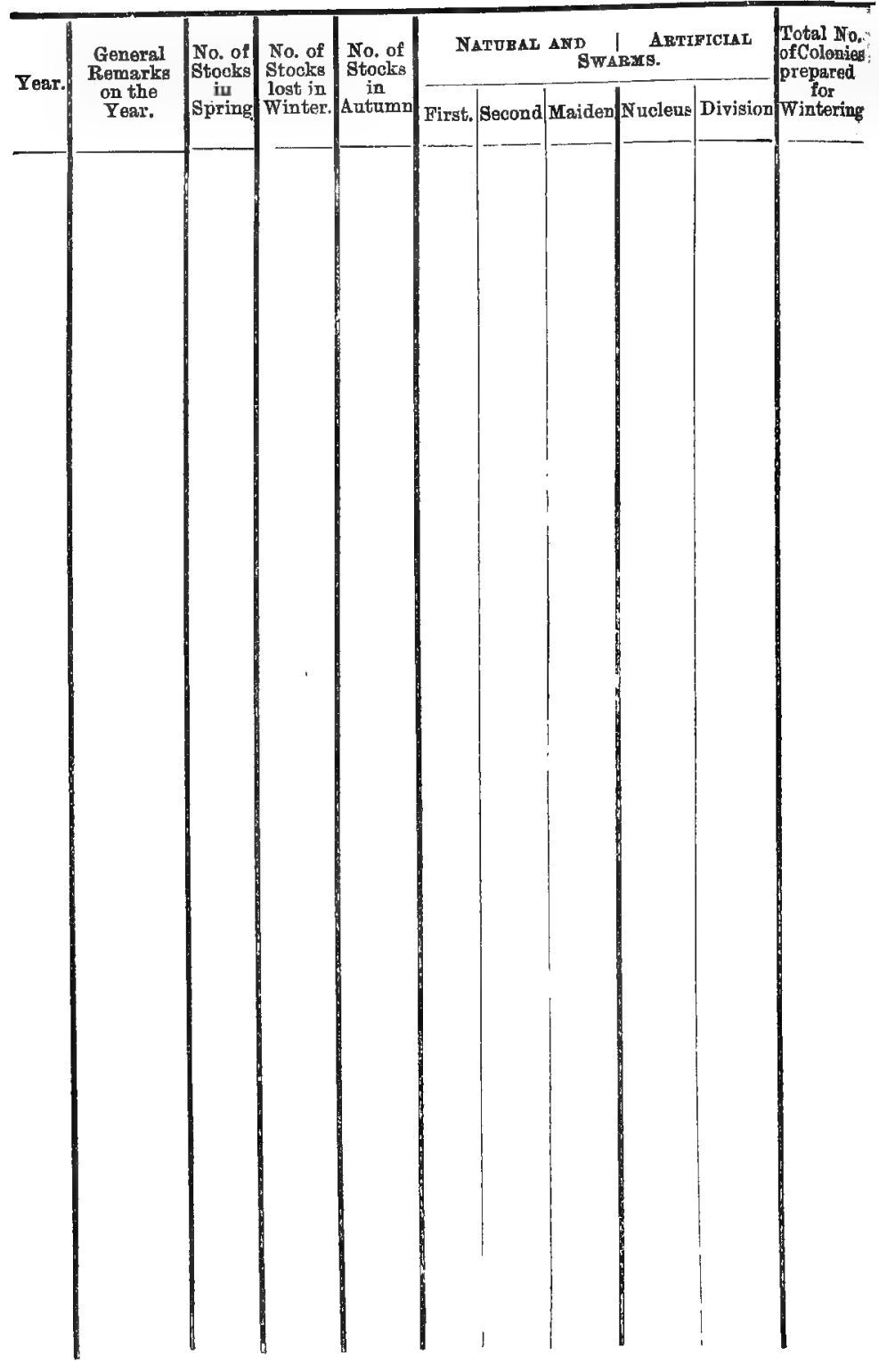




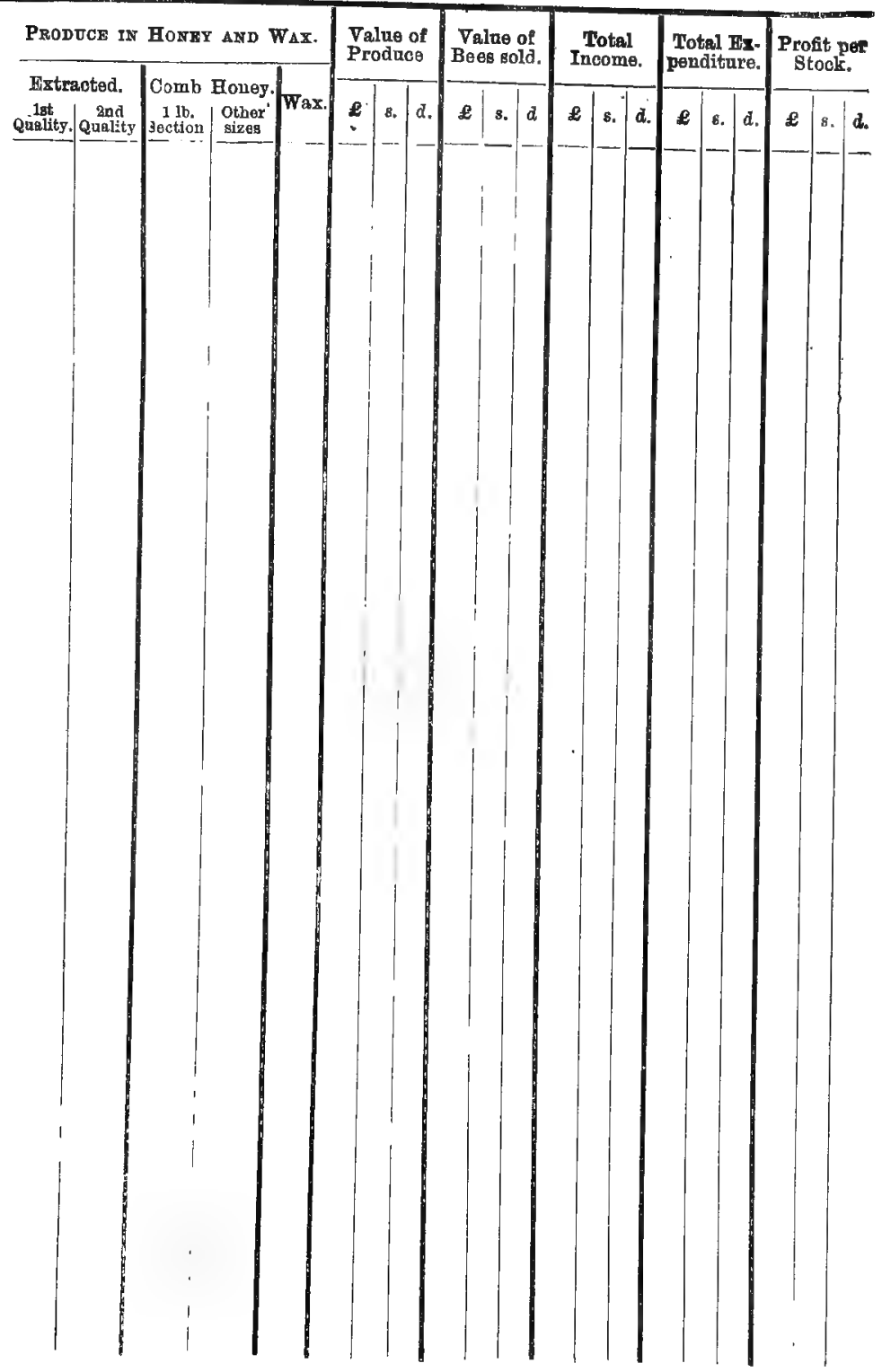



TABLE.

45

Examined in Spring, 190

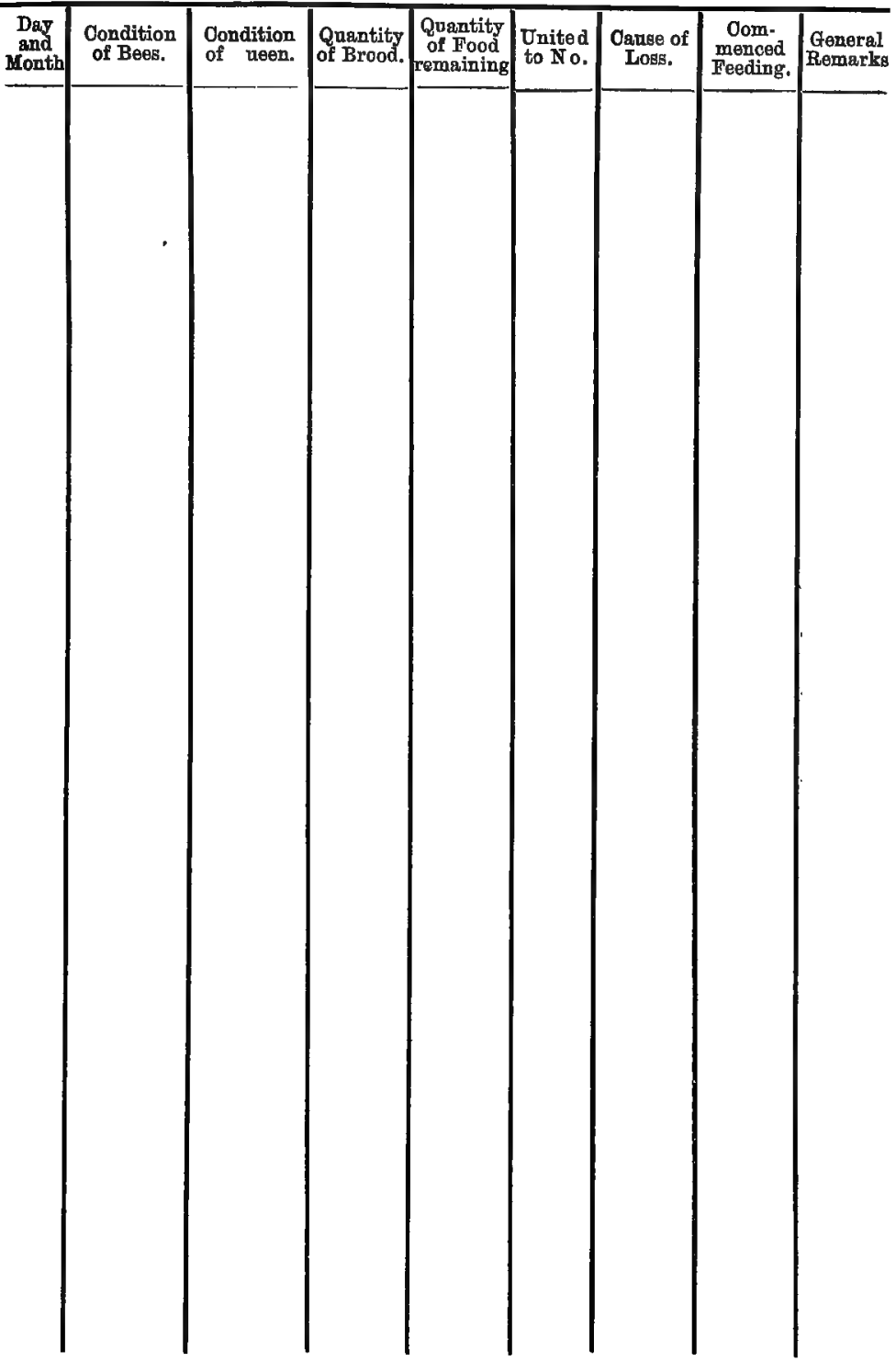



Examined in Spring, 190 .

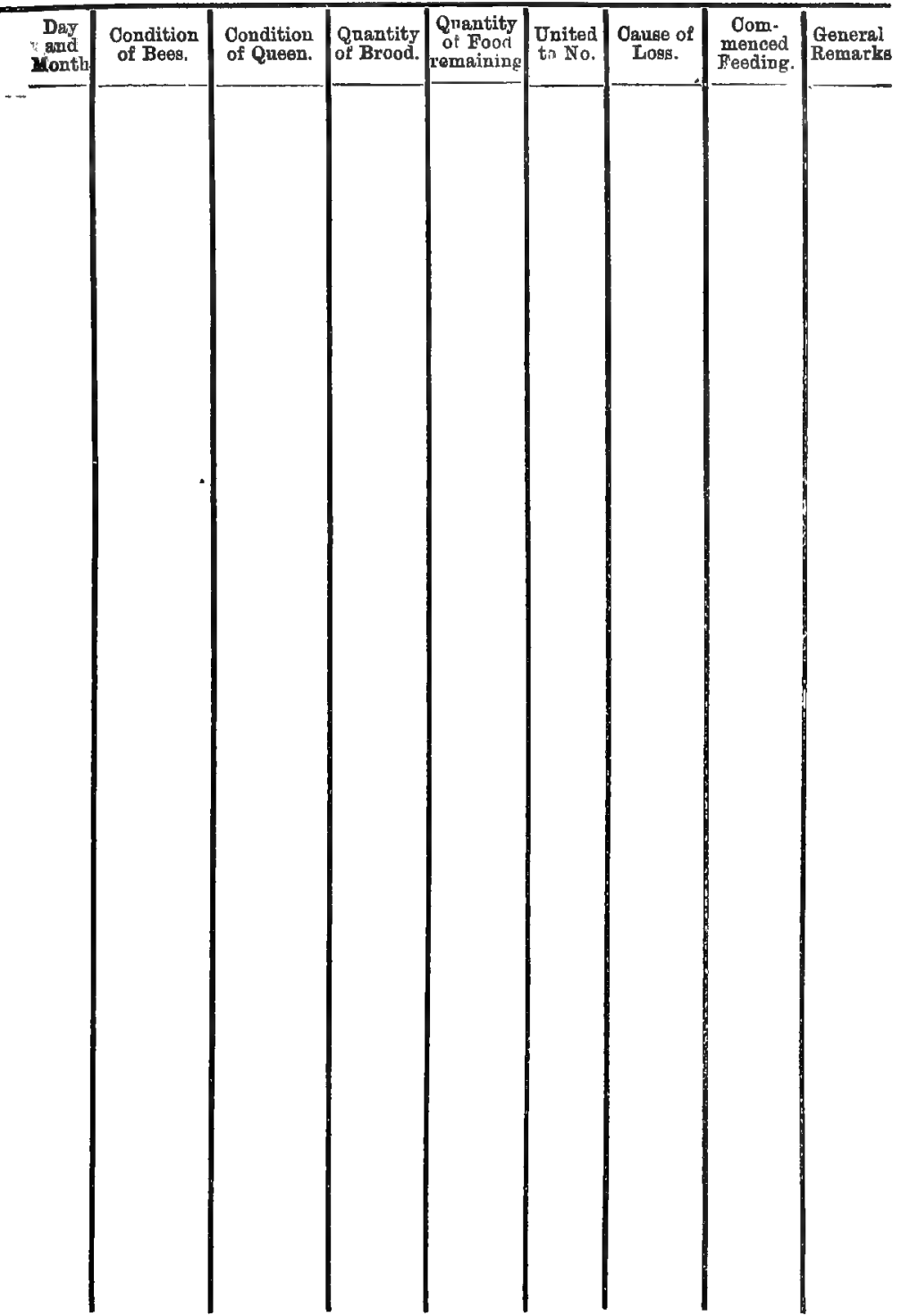



Yoar

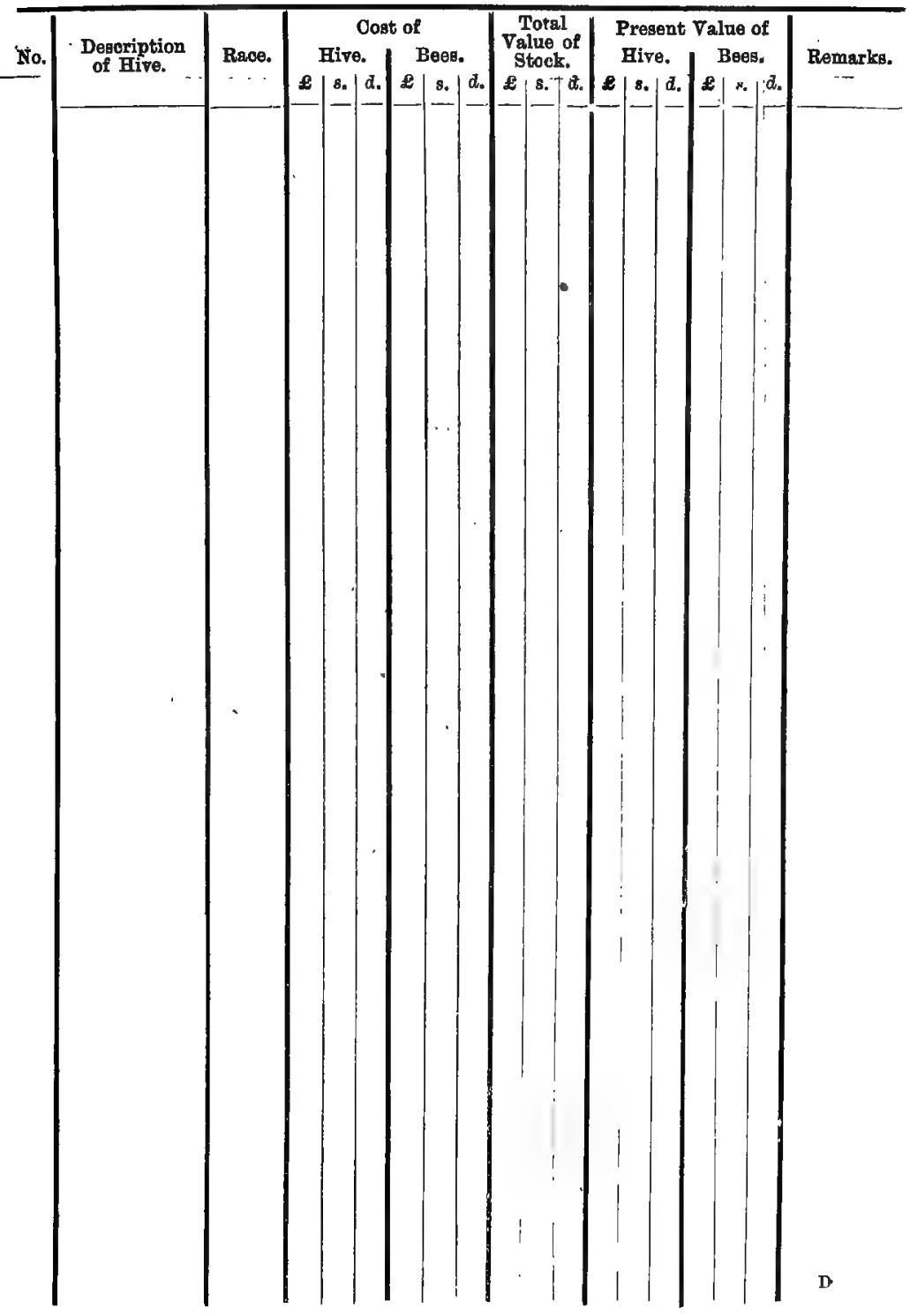


50

XII.-INCOME AND

Year

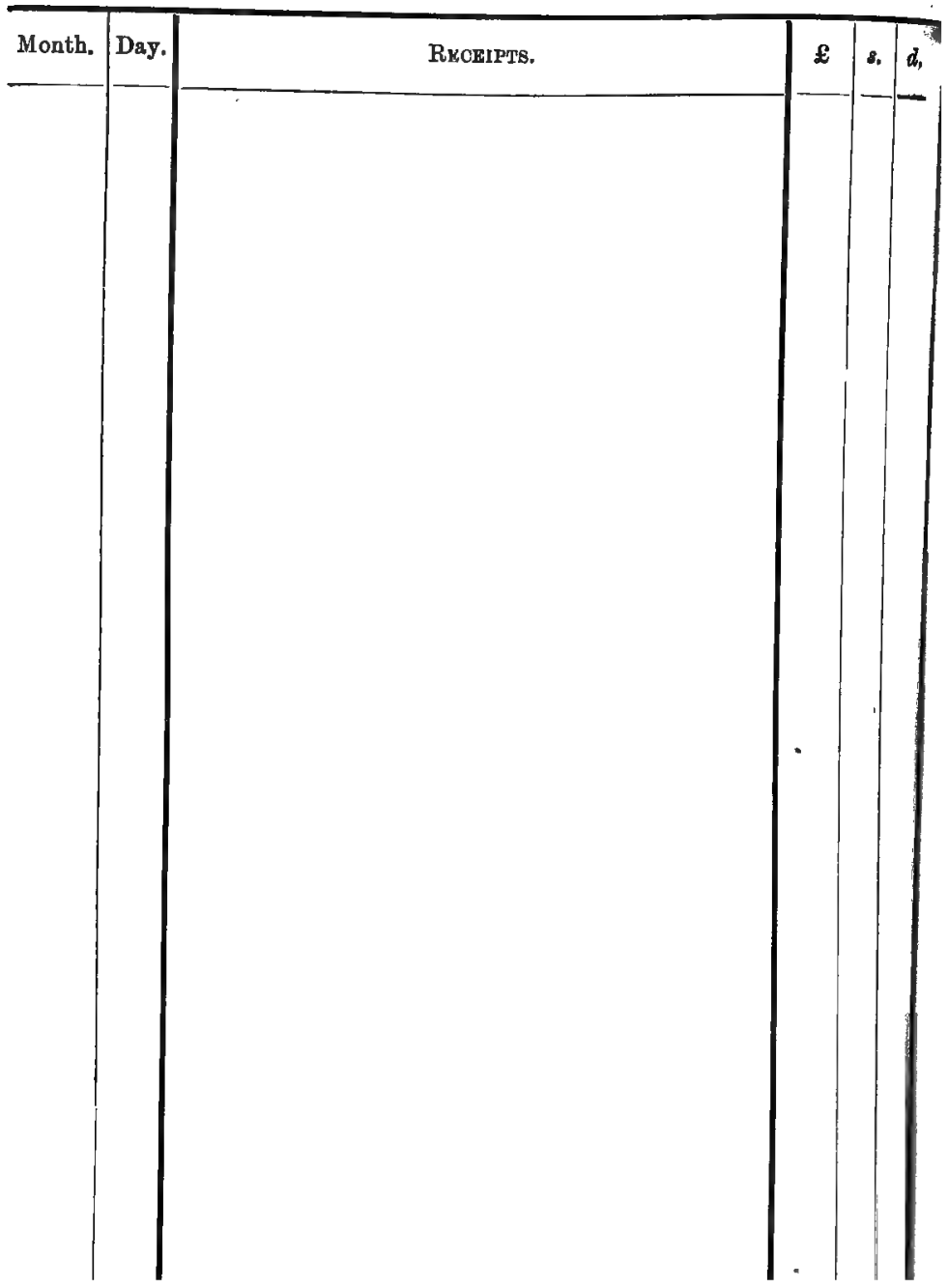


52

XII.-INCOME AND

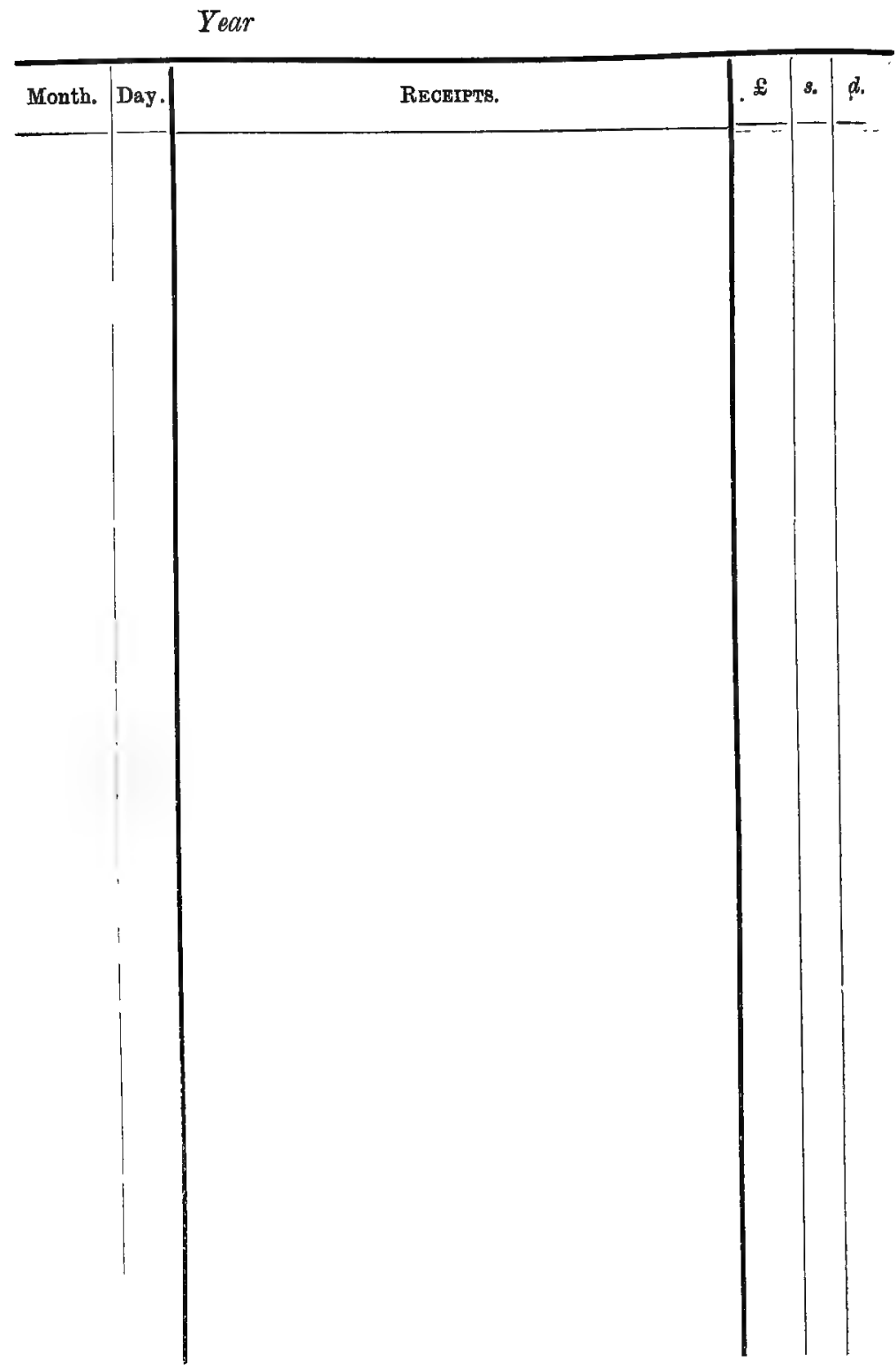


EXPENDITURE.

53

Year

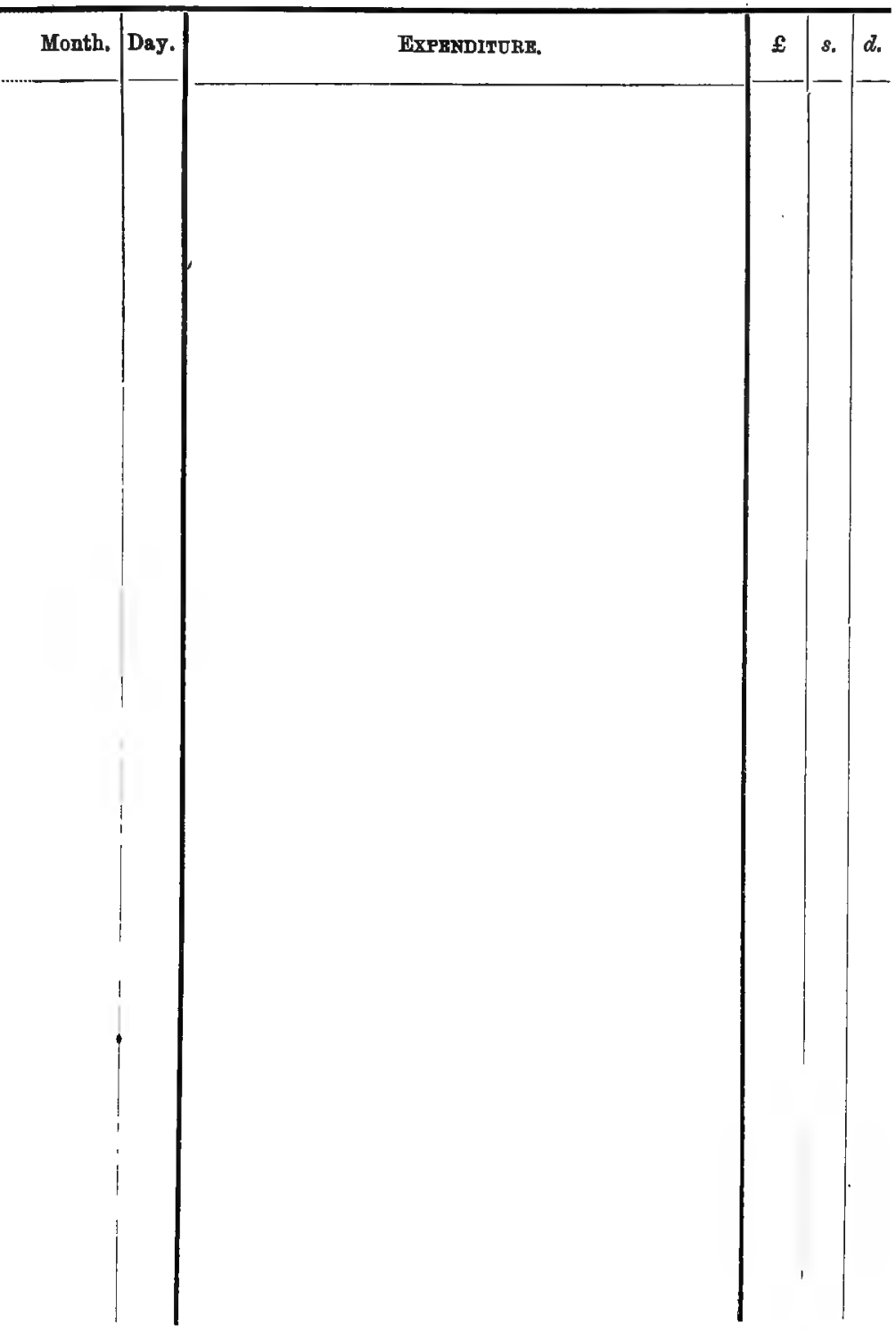




\section{THE 'W. B. C.' HIVE.}

How to Make It.

Tre long-continued favour with which the hive designated as above has been regarded shows no signs of decrease though more than a dozen years have passed since it was first brought to public notice. Nearly every bee-appliance maker in the kingdom pro-

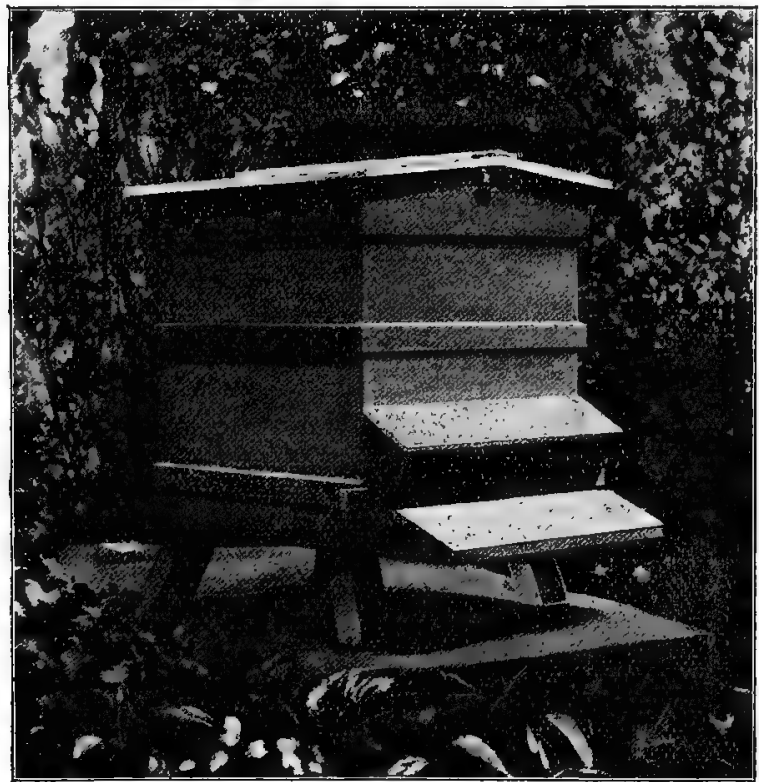

The 'W. B, O;" Hive.

minently illustrates the ' W. B. C.' in his catalogue; and although some makers, naturally desirous of keeping up to date, have added 'non-swarming' and various other so-called improvements, the original more than holds its own as a hive for general use. A striking proof of this fact occurred at the 'Royal' show of the 


\section{( 55$)$}

year 1903, when the judges (one of whom was Mr. T. W. Cowan) awarded the first prize in the class for most 'complete hive for general use' to the original 'W. B. C.,' though staged alongside hives of the same type--and by the same makers, among otherswith ' improvements' added.

So much then for its past history. And if further corroboration of what is stated above were needed, the fact of the following particulars descriptive of the hive in question having been reprinted four times, and as often sold out, surely affords it. It has therefore been decided to append them to this second edition of the Bee-keepers' Note Book, for the use of those wishing to make the hive for themselves :-

Beginning with the Floor-board (Fig. 1), the boards forming it are $\frac{1}{2}$ in. thick, tongued and grooved where joined, and nailed on to stout battens, $2 \frac{1}{2}$ in. deep by $1 \frac{1}{2}$ in. wide. Between the points at

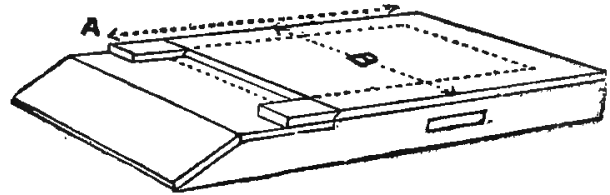

Fig. 1.-Floor-boaxd.

A on sketch it measures $20 \mathrm{in}$., and the width across at $B$ is $19 \frac{1}{8}$ in. The alighting-board projeets $7 \mathrm{in}$. beyond the point $A$. The form of the entrance, as seen sketch, explains itself ; it is $15 \frac{1}{2}$ in. long by $\frac{1}{2}$ in. high.

The Outer Case, including roof, is in three parts, the first of

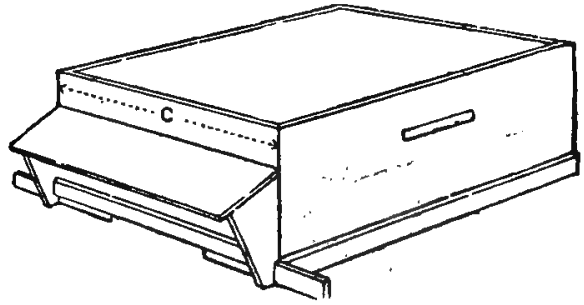

Fig. 2,-Onter Case.

which is as seen (Fig. 2). The front and back boards are $191 \mathrm{in}$. long, $8 \frac{7}{8}$ in. wide, and $\frac{1}{2}$ in. thick. Sides, $19 \times 8 \frac{7}{8}$ in. of $\frac{5}{8}$-in stuff. 
Inside measure, when nailed up, 18 in. across the front, $19 \mathrm{in}$. from front to rear. A plinth, $1 \frac{1}{2}$ in. wide, drops $\frac{3}{4}$ in. below the surface of floor-board to caury off wet. The slides for entrance are of 1-in. wood, $10 \mathrm{in}$. long by $1 \frac{1}{4}$ in. wide, and pass through a slot cut in the outer case along the guide-piece nailed across the front, below porch. The latter extends along the whole front, and is $4 \frac{1}{2}$ in. wide, with a groove cut in its lower edge to carry off drip.

The second portion of the outer case is simply a ' lift,' $6 \frac{1}{2}$ in. deep, wood same thickness as lower part, and needs no explanation beyond

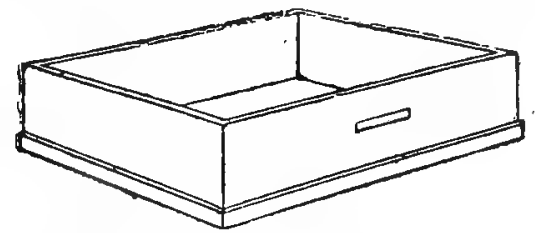

Fig. 3.-Lift.

reference to Fig. 3. This 'lift' may be removed to reduce the height of hive for winter, but we leave it on always; it keeps off cold winds when examining hive in the early season, and forms a roomy covering for plenty of top packing, \&c.

The Roof is very simple, formed with a view to lightness, and being thoroughly rainproof. The sketch (Fig. 4) will make the main points in its construction plain ; for the rest, the front and back pieces are $\frac{1}{2}$ in. thick, $20 \frac{3}{8}$ in. long, $2 \frac{1}{4}$ in. deep at ends, rising to $3 \frac{1}{4}$ in. in the centre or ridge; sides are of $\frac{7}{8}$-in, stuff, $20 \frac{1}{8} \mathrm{in}$. long, $2 \frac{1}{4} \mathrm{in}$. deep. Along the lower edge of side-pieces 2 . rabbet is cut $\frac{3}{8} \times \frac{1}{2}$ in. deep. This allows the roof to slip over the

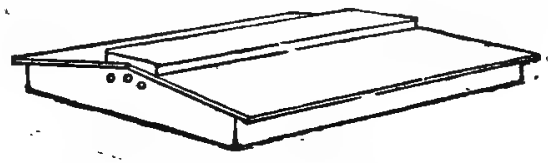

Fig. 4.-Roo․

lower portion of the outer case, and so dispense with a plinth while effectually keeping out the wet. The top of roof is of $\frac{1}{2} \mathrm{in}$. wood, each piece being $24 \times 12$ in., and they meet in the centre, the ridge-piece (of $3 \times \frac{7}{8}$ in. stuff) being cut on the under side to cover the joint as shown, so that no water can possibly get in. Hand- 
holes in each part, for lifting, complete the outer case, and we need only add that each of the separate parts fit easily over the other -no 'tightness' anywhere so long' as bees cannot enter from outside.

The Body Box (Fig. 5) is $14 \frac{1}{2} \times 15 \frac{5}{8}$ in. inside measure; it holds ten standard frames and a division-board (or dummy), along with two strips of thin wood, $\frac{3}{8}$ in. wide and $16 \frac{1}{2}$ in. long. The front and back boards are $\frac{5}{8}$ in. thick, $15 \frac{5}{8}$ in. long, by $8 \frac{1}{4}$ in. wide ; side pieces, $17 \frac{1}{16} \mathrm{in}$. long, 9 in. wide, and $\frac{3}{8} \mathrm{in}$. thick; the strip of

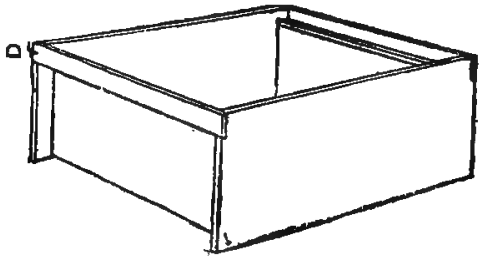

Fig. 5.-Body-box.

wood $D\left(16 \frac{3}{8} \times 1 \frac{3}{8} \times \frac{1}{4}\right.$ in.) nails on the outside to enclose the frame ends as shown. Prior to nailing on this strip, a piece of wood $\left(\frac{5}{83} \times \frac{5}{832}\right.$ in.) is secured in position level with the top edge of front and back boards, along which are nailed the tin angle-pieces, forming the 'metal runners' whereon the frames--fitted with 'W. B. C.' ends-work.

The Shallow Frame Box, or surplus chamber (Fig. 6) is an exact counterpart of body-box with two exceptions: first, the depth is reduced by 3 in.; second, the front and back boards are

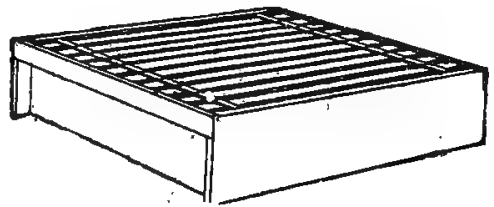

Fig. 6.- Shallow Frmwe Box.

only $15 \frac{1}{8}$ in. long. The capacity of this box is ten shallow frames $5 \frac{1}{2}$ in. deep, with ordinary ends, and two thin slips of wood, or eight similar frames fitted with wide 'W. B. C.' ends. 
The hive, as described, is without legs, and we use the Stand (Fig. 7). To a casual observer, the stand is simply four legs and four side-pieces nailed together, and will perhaps suggest. a very

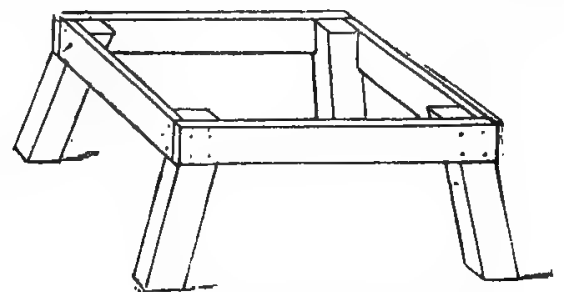

Fig. 7.-Stand.

fragile, shaky affair. But it is as firm and rigid almost as if made of cast iron, and the secret of this firmness is in the peculiar way in which the leg is cut, and the 'collar' of wood fitted on to it.

To any one who understands the use of a bevel, the

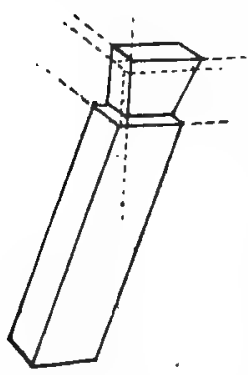

Fig. 8. sketch (Fig. S) of one leg here given explains itself to a joiner, but the amateur may require a few words of explanation. So let him take a piece of scantling $3 \times 2 \frac{1}{2}$ in, and cut up into lengths, as sketch (Fig. 9), according to the number and height of the stands required. He then arranges the legs in pairs and marks them off with the bevel, to give a 'splay' of about $2 \frac{1}{2}$ in. from the corners, so that, when cut, the legs are 'splayed' outwards on all sides. The idea will be seen in diagram (Fig. 10), and made from $\frac{3}{4}$ in. stuff, is nailed on, and the sketch (Fig. 7), given sisting 'set' of the legs when the 'collar'-

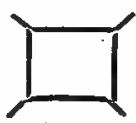

Fig, 10. and $2 \frac{1}{2}$ in. widestand completed asin above, there is a refrom whichever side pressure is used. Stands must be made to fit the floorboards used.

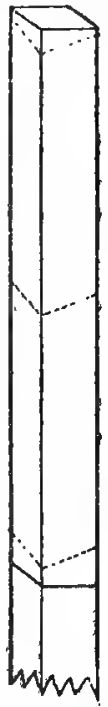

Fig. 9.

The 'eke' (Fig. 11) may be described as a slice, 3 in. deep, from the lower side of the body-box (Fig. 5), and, beyond stating that the four slips of wood shown on the upper edge are for keeping 
it in position when fixed, the sketch explains itself. This 'eke' may be used for giving space below combs in winter, and, having served this purpose, by reversing and setting it above frames in

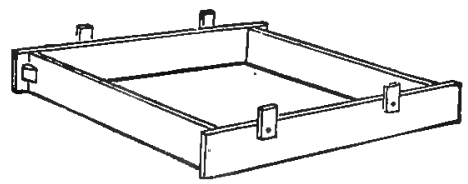

Fig. 11.-'Eke.'

early spring, it helps in 'tucking in' additional warm wrappings. Finally, when set below the shallow frame box (Fig. 6), it converts the latter into a full-sized brood-chamber for standard frames.

January 1904.

W. B. C.

In the foregoing somewhat lengthy description we have given full details of the 'W. B. C.' hive, in order that there may be no mistake with regard to the form and measurements of its various parts. It was absolutely necessary to do this in view of the numerous so-called 'W. B. C.' hives now on the market, differing more or less in important details to such an extent that we decline to acknowledge the right of makers to so designate them.

At the same time we admit the difficulty some amateur joiners will find in working out a necessarily long array of figures and fractions of inches. The same thought evidently occurred to our friend Mr. Robert Peebles, of Edinburgh, an experienced bee-keeper, who himself used no other hive but the one in question. Anyway, $\mathbf{M r}$. Peebles some years ago kindly took the trouble to write for publication in the British Bee Journal an alternative plan, which would not only overcome the difficulty, but, as he said, would render 'the making of a "W. B. C." hive as plain as A B C."

We therefore append Mr. Peebles' plan-with his own illustrations-as described by himself.

\section{Mr. Peebles' Plan of Making a 'W. B. C.' Hive.}

IN order to assist those who are able and willing to help themselves in constructing a ' W. B. C.' hive, I have prepared a plan and 


\section{$(60)$}

two sections, drawn to the accompanying scale, which will, I believe, place the details and measurements of this most nseful hire within the power of any such to comprehend or, indeed, commit to memory while working.

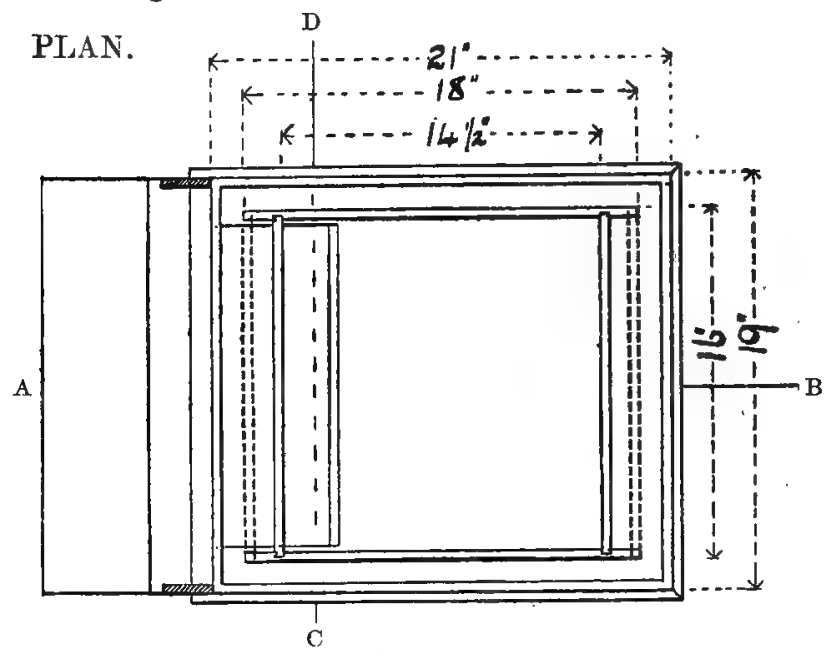

Keeping strictly in view the original description as given by the designer, and avoiding technicalities and fractional parts of an inch as much as possible, the principal dimensions will, for all practical purposes, be found correct. The outline tracings are

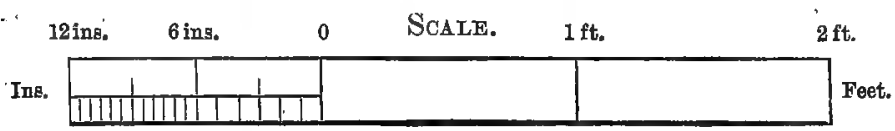

from drawings of my own hives, made in 1892, and the following description applies to them :-

The floor-board, covering of 'roof, casings, body and surplusboxes, are made of selected American yellow pine half an inch thick off the saw, and if cut with the perfection of nowadays, all the dressing required is a skim over with a hand-plane to remove the saw marks. If this is attended to, it will be found, when the hive is put together, that the outside sizes marked on plan tally 


\section{( 61$)$}

with the principal inside dimensions originally given by ' W. B. C. himself.

The frames of the stand and roof, as well as the hive proper, are dovetailed (not simply nailed) together. Where required screws are alone used, and these are previously dipped in paint, the overlaps and plinths being serewed from the inside. Where the wood overlaps, it gets two coats of white or red lead and oil previously. There are no hand-holes, the plinths of the case and the ledges on

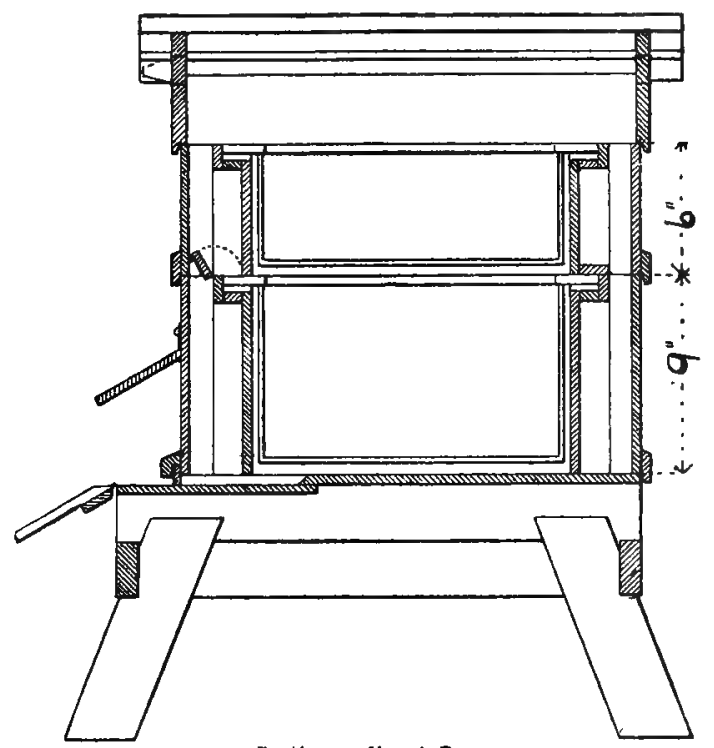

Section on line A. B.

boxes filling the requisite. The plinths are bevelled on inside edge as shown. It will be observed that the end-pieces or kerbs are also half an inch thick; this is necessary for hinging the narrow flaps to-one of which is shown partly open-the other shut down. These flaps are used primarily for covering the exposed ends of topbars, and for keeping the surplus chambcrs in position.

I have great pleasure in preparing the tracings and description for your personal consideration and for the benefit of your readers. My desire has been to make everything simple and easy to under- 


\section{( 62$)$}

stand by an amateur joiner of ordinary intelligence. For myself, I will grudge no labour of mine if it will help to make the ' $W$. B. C.' hive properly and easily understood. When the description and drawings of the hive first appeared in print I at once detected a

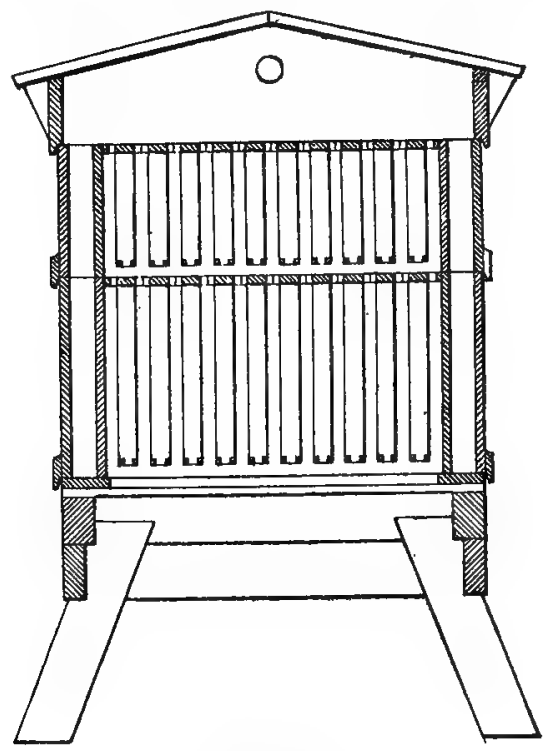

Section on line O.D.

few slips, easily remedied by a practical joiner; but the thing most needed was sectional drawings to explain things without so many detailed measurements. I therefore say, Why cannot the 'W.B.C.' hive be made as plain as A B C? It shall!

Robert Peebles. 


\section{$(63)$}

\section{A HOME-MADE HIVE.}

Constructed from Used Boxes.

\section{By Harry Clarise.}

UsED boxes are not, as a rule, advocated for the making of beehives, I know, on account of the joining up required if the wrong sort of boxes are used; but from the right sort of boxes very good hives can be made. I enclose a photograph of one made by myself from boxes (see page 64), and, as will be seen, no paint has been used to hide imperfections.

The boxes used are:-(1) An egg-box; (2) lobster-box; and (3) 'Quaker Oats' box. The cost of the boxes is $1 s .1 d$.

The Stand.-Cut four pieces from the thickest board of an eggbox, 26 in. long and $4 \frac{1}{2}$ in. wide. Put the pieces in pairs and nail each pair together' then at one end cut slanting from 2 in. at the bottom to full width of the board at the top, far enough back to allow a 6-in. alighting-board to be nailed on. Then cut two pieces and nail together to form the crosspiece at the back, measure from the back $19 \frac{1}{2}$ in., and fill up to the alighting-board with another piece of the egg-box.

Floor-board.-For this take the end of a 'Quaker Oats' box, and after cutting off the dovetail ends cut two pieces from the other end of the box and nail on to the sides; this will not only make the floor-board the full width, but will keep it from twisting. Cut out entrance in the centre of the front, $\frac{3}{8}$ in. deep by 9 in., and back into the floor-board about 2 in., then gradually slant up to level.

Outer Case.-Take the four cross-pieces of the egg-box.; these will be found to measure $9 \frac{1}{4}$ by $19 \frac{3}{4}$ in. by $\frac{3}{4}$ in. Cut two pieces $18 \mathrm{in.}$ long, and two pieces $19 \frac{1}{2}$ in., and after planing nail them together, forming a bottomless box $19 \frac{1}{2}$ in. square. Then cut from the sides of the egg-box three pieces, $3 \mathrm{in}$, wide, to form plinths for the back and sides of the outer case; these serve the double purpose of keeping the floor-board in position, and preventing the body-box from being moved out of its place in rough weather.

The entrance-slides can be made by cutting one piece of wood $\frac{1}{2}$ in. wide, and one piece $1 \frac{1}{2}$ in. wide, nailing together, so as to form a rabbet. Nail on to the front of the hive, level with the 


\section{$(64)$}

bottom of the outer case, and fit two pieces to slide in the groove, For the porch, cut two small hrackets, and nail on a board $19 \frac{1}{2} \mathrm{in}$. long by 4 in. wide.

Body-box (or Broodtchamber).--Take the four pieces of the lobster-box measuring y $9 \frac{1}{2}$ in. by 20 in., cnt two pieces $8 \frac{7}{8}$ in. by $17 \frac{1}{8}$ in., and two picees 81 in. by $16 \mathrm{in}$., the latter to be chamfered on the top elge. Nail these at equal distances from each end of the longer pieces, so that the inside measurement is $1+\frac{1}{2}$ by 16 in.

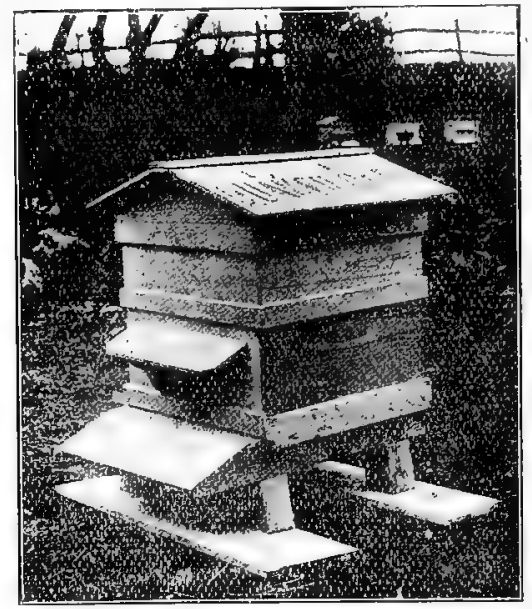

Hive made from Used Boxes.

This is important. The space to the end of the side pieces can be filled up with the picces cut off in reducing, nailing them a little lower than the chanfered edge to form a finger-hold; and two other pieces about $2 \mathrm{in}$. wide, nailed up to the end to keep the frrmes in position, finishes the body-box.

Lift.-Take one of the 6-in. picces of the egg-box, and make another bottomless box, the same outside measurement as the outer case of the body-box, but with plinths nailed on all round.

Roof.-Cut two pieces from the side of the egg-box, $20 \mathrm{in}$. long and 4 in. wide; also two other pieces, $6 \frac{3}{4}$ in. by $19 \frac{5}{8}$ in. Mark the centre of the latter, and cut off slanting to $t$ in. deep on each side; then nail the four pieces together. For the top, use the two sides 
of a 'Quaker Oats' box, measuring $1 \mathrm{ft}$. by $2 \mathrm{ft}$., and a further piece 2 in. wide, nailed along the ridge, to prevent any wet getting through the join. This will fit over the lift or body-box, and, to prevent it going too far down, four small strips should be nailed inside, about $\frac{1}{2}$ in. from the bottom.

\section{HOW TO BUILD A BEE-HOUSE.}

\section{By 'A. Worker BeE.'}

For details of construction to accompany the sketch-plan sent, I am afraid that I should find it an easier job to build the house than tell how it should be done. I say this because I am more used to handling tools than the pen, so please correct mistakes. First then we take the floor :-(1.) Get two lengths of stuff $\tau \mathrm{ft}$. $10 \frac{1}{2}$ in. by 4 in. by 2 in.; merk off 2 in. from each end for mortise 1 in. thick in centre of 4 in. way. (2.) Next take two pieces $5 \mathrm{ft} .10 \frac{1}{2}$ in. by 4 in.

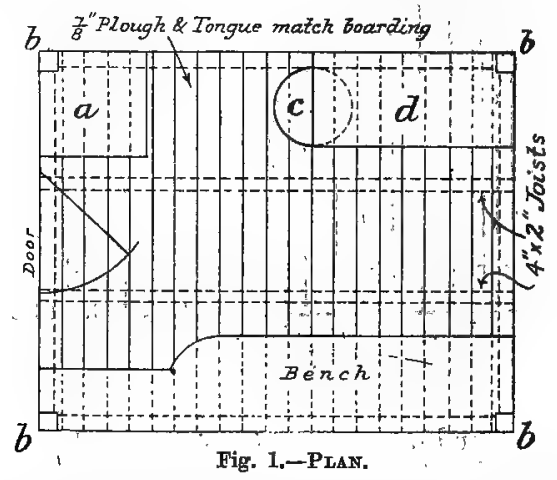

by 2 in., mark 2 in. off each end ; cut tenon to fit mortises. Knock together. (3.) Get two pieces of batten $1 \frac{1}{2}$ in. by $\frac{3}{4}$ in.; 'nail on inside bottom edge to take the ends of middle joist. "Cut three 4 in. by 2 in. to fit between, so that the top edges come level; fasten all firmly together. Keep all rounding edges upward. (4.) Give a coat of black varnish all over. Lay on $7 \mathrm{in.} \mathrm{by} \mathrm{l}$ in. tongued and grooved square-edge matchboards and fasten same down. We now come to the front :-(5.) Take two pieces 2 in. by 2 in. red deal $6 \mathrm{ft}$. long; mark off 2 in. each end and one 2 in. in centre, and mortise same, then take three rails 2 in. by 2 in., $7 \mathrm{ft} .10 \frac{1}{2}$ in. ; tenon these ends; 


\section{$(66)$}

drive well together. Our next job (6) deals with the back of house. For this use two pieces $8 \mathrm{ft}$. long ; mark off 2 in. each end, 2 in. in centre. We then need three rails same length as front; tenon and drive these together. Finally we come to the ends of our house. For these cut three pieces $5 \mathrm{ft} .6 \frac{1}{2}$ in. for end opposite door. On the inside of these screw an iron angle-bracket.

Put these latter so that when the back and front are in place the respective squares can be screwed to the rails of back and front end, one of which has the door in it. (7.) Cut one piece 5-ft." $6 \frac{1}{2}$-in.

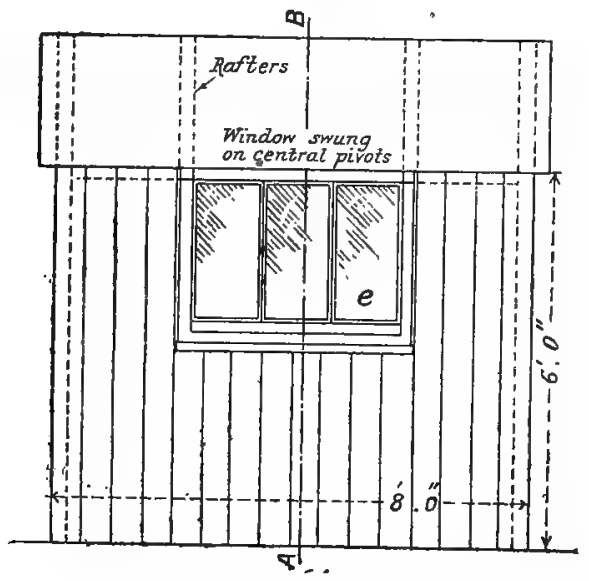

Fig. 2,一FLETATION,

board, find centre, and mark off width of door each side; the door is four boards wide, i.e., two boards in width on each side of centre; mortise for uprights ; teuon uprights to fit. Bore a small hole in bottom of uprights (to take a $\frac{1}{2}$-in. iron pin), and bore hole in floor to correspond; then screw two more of the angle-brackets to end of this rail. (8.) Place floor where it is to stand on four bricks. Fix up the front and back on it, and stay them in their places. Screw the end rails up in position. The framework will now be in its proper place. Get some pieces of 2 in. by 2 in. scantling for rafters; notch them a little to bear on front and back (do not nail them down) You will now need a few cabin-hooks and eyes, and these must be fastened on so as to be easily hooked or 
unhooked. Nail on $\frac{3}{4}$-in. matchboards, letting them project over the frame 2 in. each way.

Be careful that an extra rafter is placed 4 in. from each end of frame, and that the roof-boarding is only fastened to this so that the roof may be lifted off if required for the purpose of shifting. Nail $\frac{3}{4}$-in. boards on back, well painting tongues and grooves wherever the wood bears against rails. Repeat these directions with the end opposite door, except that the last board on each side must be sereved, and on no account must the boards be nailed to joists. For front get a $4 \mathrm{ft}$. long by $2 \mathrm{ft} .10 \mathrm{in.} \mathrm{high,} 3 \mathrm{in}$. by $2 \frac{1}{2} \mathrm{in.} \mathrm{casement}$ or window frame, hung in centre on pivots so as to swing the sash

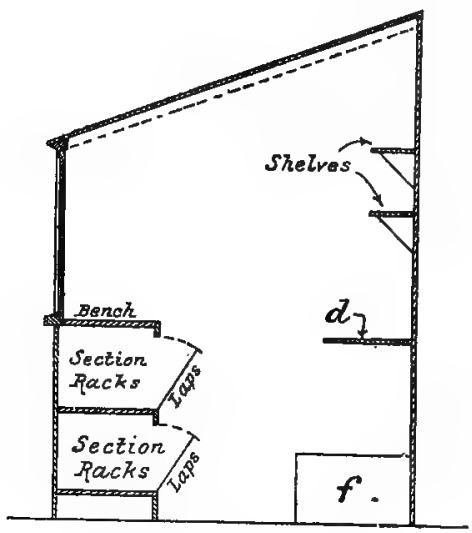

Fig. 3-Szctron at A, B.

round easily. Rebate it round the thickness of board ; fix in centre of top half ; board it round. The end for door is made in the same way, except that the two outside boards are screwed.

It will then be seen that the frame of house rests with bottomrails on floor ; framework to be made so that the outside of frame is flush with outside of floor. The $\frac{3}{4}$-in. boards will then cover frame and sides of joists, and also keep the whole thing rigid. The floor carries the whole weight of house.

If constructed like this, one will be able to take the house to pieces for moving if required. The door is made to suit opening, fitted with rim-lock, and hung with 1-in. T-hinges. Door is shown as opening inwards in sketch, but it might be more conveniently 
opened outwards to give extra room. Under the window inside fix a bench, as shown, consisting of three widths of 7 -in. by 1 -in. tongued matchboards ; under this two shelves, as shown, are made of $1 \frac{1}{2}$-in. by $\frac{3}{4}$-in. battens; nail on to ledges leaving a space between each batten; fix bottom shelf 3 in. above floor, the other midway; fill up space from bottom shelf to floor with strip of wood; hang two long $\mathrm{n}$ arrow doors to close openings between shelf; fit them nicely, and when complete this makes a good place to keep extracting-frames and sections; a few balls of naphthaline are placed under bottom shelf ; fix shelves to back on brackets; make all inside fixtures removable.

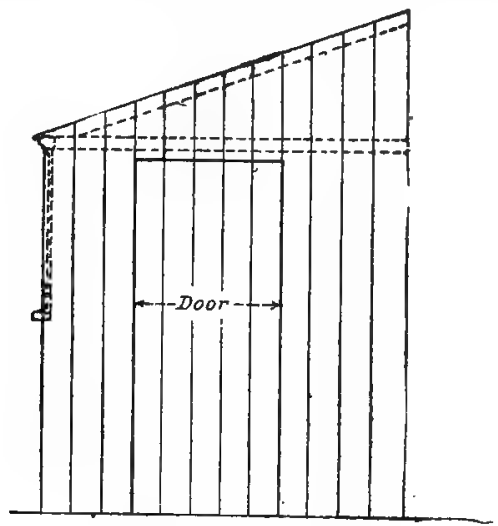

Fig. 4.-SIDE VIEW.

In corner fix up a small platform $1 \mathrm{ft}$. high, 24 in. square, for Extractor to stand on. Two brackets of wood 2-in. by 1-in. are next wanted. Hinge them on to a piece of 2 -in. by 1-in. stuff, and screw this against back, letting one be an inch higher than the other, and fixing them about $3 \mathrm{ft} .10 \mathrm{in}$. apart. Then get a piece of white wood $4 \mathrm{ft} .6$ in. long by 17 in. "wide, and in this make $\nabla$-grooves 2 in. apart, cut lengthways. Screw some small brass 'plates on its edge. When done, place this on the brackets for a draining-board to stand boxes of shallow frames on after being through the extractor. It can also be used as an 'uncapping-stand.' - Cover the draining-board with a couple of coats of pure shellac varnish, and then it will be able to be kept clean with little trouble. 


\section{SHORT RULES \\ FOR THE GENERAL MANAGEMENT OF MOVEABLE COMB-HIVES.}

\section{I.-SPRING.}

DURing farourable weather at the end of March, take the opportunity of examining and ascertaining the condition of every hive. Contract the size of the hive with division-boards, so that the bees have only as many combs as they ean occupy. Examine each comb as it is removed, and ascertain the presence of the queen. If she has commenced to lay, she may be further stimulated by uncapping some of the honey-cells. Gentle feeding, either with syrup or flour-candy, should also be resorted to if the bees are likely to run short of food. If the colony is found queenless, unite it to one having a fertile queen. Should the queen be a drone-breeder, she should be destroyed, and the bees united to another colony. Keep the hives well covered and warm, and disturb as little as possible. Take care only to open on warm days, so as not to chill the brood. As brood increases and the hive gets crowded with bees, breeding may be further stimulated by spreading the brood very cautiously, and continue gentle feeding with liquid food. It is better to give the food at night, to prevent robbing ; also, for the same reason, open hive-entrances only in proportion to the strength of the colony. When warm weather induces frequent flights, provide a drinking-trough for the bees, and induce them to visit this by adding a little honey and salt to the water. Provide artificial pollen as long as the bees will take it. As breeding and the strength of the colonies increase, equalise the stocks by removing frames of brood from those having an abundance, and giving them to weaker ones. 
Fill the empty spaces caused by the removal of these with empty comb or comb-foundation. It takes about six weeks to build up a colony of sufficient strength to take advantage of an early flow of honey. Prepare for queen-rearing early in April, according to the instructions given in the British Bee-keeper's Guide Book. In the beginning of May, if the weather be favourable, the winter chaff packing may be removed, and the frames and bees transferred to clean hives, giving them also clean floor-boards. Continue gentle feeding until the incoming honey exceeds the daily consumption. Be on the look-out for foul brood, and if present commence treatment with naphthol beta and naphthaline as directed in Guide Book withont delay.

\section{II.-SUMMER.}

Prepare racks of sections for use by putting comb-foundation in the boxes, and when the bees begin to store honey in large quantities place frames of sections with separators at the side of the brood-nest, and as soon as the foundation in these becomes drawn out, they can be removed with the adhering bees and put into the rack on the top of the hive. This will induce the bees to take to the supers more readily. As fast as any of the sections on the top are completed, they should be removed and stored away in crates. Two or even three racks of sections may be worked at the same time. Towards the close of the season the sections may be finished off in one rack. To prevent the bees swarming, give them additional room in advance of their requirements. Extract when necessary to relieve the brood-combs of superfluous honey, and give the queen room for laying. Should the bees persist in swarming, remove all the combs, give frames of comb-foundation, and return the swarm; this will generally stop the swarming fever, and not interrupt the work in the sections. Double those colonies intended for extracting, and extract at suitable intervals. Make artificial swarms if required, and check swarming by cutting out queen-cells, extracting honey, and removing frames of brood. 


\section{III.-AUTUMN.}

Examine all hives, feed when necessary, and unite all weak colonies. Introduce queens to queenless stocks, and if necessary to reduce the number of frames, leave only as many as the bees can well crowd, and close up with division boards. About 25 to 30 pounds of food stores would be sufficient to leave, and extract all unsealed stores beyond a couple of pounds or so. Cut winter passages through the combs, and make passages over the frames by placing sticks under the quilts. Place warm coverings above frames, and reduce the size of entrances. Prepare honey for market, sort the sections into first and second quality, and put into crates holding twelve to twenty-four. Put the extracted honey as soon as possible into jars, before it begins to granulate, and label neatly.

\section{IV.-WINTER.}

If properly attended to in the autumn, the bees ought not to be disturbed until the spring. Shade the entrances of hives, and prevent the sun's rays entering to entice the bees to come out. Guard against the attack of birds and mice. Clean and prepare hives for spring use, and purchase or make any new apparatus required, so as to be in readiness in the spring. Boil up old combs and extract wax.

Should feeding have been neglected in the autumn, place a good-sized cake of soft candy above feed-hole in quilts, or under the quilt over the cluster of bees.

For full information upon working Moveable Comb Hives, read and study the British Bas-keeper's Guide Book, by the same author.

As a knowledge of the natural history and habits of the honey bee is of the greatest assistance to the bee-keeper in his practical work, he is recommended during the winter months to study The Honey Bee: its Natural History, Anatomy, and Physiology, by the same author.

Londnn : Printed by Stranarways and Sons. Tower Streel Gambridge Circus. W.d. 






\section{BeE PUbligations, \&o.}

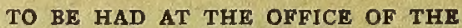

\section{'British Bee Journal' \& 'Bee-Keepers' Record.'}

Worke by T. W. COWAN, F.G.S., F.T.S., Le.

THE HONEY BEE: Its Natural History, Anatomy, and Physiology. New edition Thoroughly revised and brought up to date, $2 s .6 d$.; or post free, $2 s .81 d$.

BRITISE BEE-KEEPERS" GUIDE-BOOK, 50th Thousand. Is. $6 d$; ; or post free 15. 8d. Cloth Gilt, 2s. $6 d$; ; post free, 25. 81d.

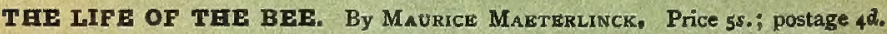

Mr. Cowan, in his review of Maeterlink's work, says :- Not since the appearance in $\pi 876$ of Buichner's "Mind in Animals," have we had a book about bees more charming or one that we had read with greater pleasure than Maeterlinck's "Life of the Bee."

BRITSE BEE-EEEPERS" NOTE-BOOK, New edition. Revised and enlarged. 15. : or post free, $x s, 1 d$.

PHOTOGRAPE OF FOUL BROOD. With Description by $T$. W. COWAN. is. post free.

BEE-KEEPING : Its Excellence and Advantages. By S. J. $3 \frac{2}{2} d$. post free.

\section{Publlabed by the

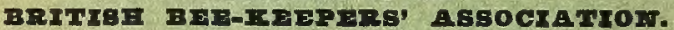

MODERN BEE-KEEPING, Ninth edition. Thoroughly revised, $6 d$.; or post free, $7 d$.

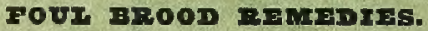

NAPHThALINE. For use in Hives as a Preventive of Infection. In boxes, Is. post free.

INAPETHOL BETA. For use in Medicating Bee Food. is, per packet post free.

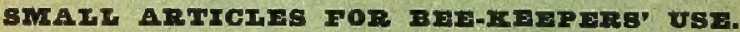

' RESA.' Antidote for Bee-stings, Bites of Mosquitoes, Gnats, \&ce. In neat nickelplated case for vest packet. Is. Id. post free.

THE 'RET' GLASS HONET.TASTER, In case, ss. post free.

\section{Pura cavis Bugat:}

For Bee-Food at Current Rates.

All the above may be had at the prices affixed on receipt of remittances,

Cash to Accompany all Orders,

NOTE. - In order to avoid a frequent cause of trouble in writing, it should be understood that no Hives or Bee-appliances of any kind whatever are dealt with at the office of the 'British Bee Journal,' or 'Bee-Keepers' Record.' 